\section{Віктор Коцур}

Академік НАПН (дійсний член)

доктор історичних наук, професор.

Ректор Університету Григорія Сковороди

в Переяславі

(Переяслав, Україна)
Dr. hab., Acad. Victor Kotsur

Academician (the real member) of the

Academy of the Educational Sciences,

Doctor of History (Dr. habil.), Professor.

Rector of the Gregory Skovoroda University

in Pereyaslav

(Pereyaslav, Ukraine)

ORCID: https://orcid.org/0000-0003-4968-4813

ResearcherID: 1760067/victor-kotsur/

phdpu.edu@gmail.com

\title{
НУМІЗМАТИЧНЕ ЗІБРАННЯ НАЦІОНАЛЬНОГО ІСТОРИКО-ЕТНОГРАФІЧНОГО ЗАПОВІДНИКА «ПЕРЕЯСЛАВ»
}

\section{THE NUMISMATIC COLLECTION OF THE NATIONAL HISTORICAL-ETHNOGRAPHIC RESERVATION «PEREYASLAV»}

\section{Анотація.}

Мета статmi. Головна мета статті полягає у введенні до наукового обігу матеріалів нумізматичного зібрання НIЕ3 «Переяслав», вивчення його структури та виокремлення найбільш цікавих у контексті історії Переяславщини зразків монет. Методологія дослідження. У процесі наукового опрацювання колекиії заповідника було використано загальнонаукові методи: аналітичний, ілюстративний, хронологічний, типологічний, а також джерелознавчі методи: критичний, метрологічний та іконографічний. Наукова новизна полягає у тому, що вперше до наукового обігу введено комплексне дослідження всієї нумізматичної колекиії заповідника а також наведено дані про археологічні знахідки Переяславщини, що потрапили до музею. Опублікований у статті каталог (інвентарний список) монет слугуватиме додатковою джерельною базою для дослідників історії грошового обігу Київщини.

Висновки дослідження. В умовах активного поширення $\mathrm{m}$. зв. «чорної археологї̈» з їі низькою достовірністю та часто сумнівністю отримуваних даних, з обмеженою можливістю використання відповідних знахідок у нумізматичних дослідженнях актуальним для сучасної нумізматичної науки стало введення до наукового обігу та дослідження музейних колекиій. Нумізматична колекиія НІЕЗ «Переяслав» була досліджена досить фрагментарно: науковиями введено до наукового обігу фальшиві монети Речі Посполитої та традиційні жіночі прикраси - «дукачі», співробітниками археологічної експедиції музею регулярно публікувались результати пошуків на Переяславщині та нові надходження знахідок до музею. Колекція нумізматики НІЕ3 «Переяслав» налічує більше 12.000 монет від Римської імперії до ХХ століття. Частина предметів нумізматики на сьогодні експонується у приміщеннях заповідника. Монети XVII-XVIII століття, карбовані у Західній Європі, Речі Посполитій та Московії, експонуються у відділі «Музей Заповіту», жіночі прикраси для одягу - «дукачі», також експонуються у філії «Музей украӥнських обрядів». До музею протягом останніх 20 років надійшли монети, знайдені археологами на Переяславщині: античні монети Римської імперії, монети Київського князівства, Візантії, Речі Посполитої та ї̈ васальних у XVII столітті земель. У нумізматичній колекиії НIЕЗ «Переяслав» збережено 47 талерів 
Західної Свропи, які повністю відповідають специфріці грошового обігу регіону. Окраса музейної колекції - карбований за часів реформи Олексія Михайловича «єфімок 3 признаком» 1655 року. Досить значну за кількістю частину колекиії складають монети Російської імперії. Особливу иікавість викликають монети Петра I-алтини, гривеники, рідкісні полтини та рублі правителя. Також у колекції музею представлені срібні рублі 1730-х років, прикрашені деталізованими портретами російських імператриць - Ганни Іоанівни та Катерини І. Окрім того на Правобережжі були поширені монети, карбовані у Царстві Польському на монетному дворі у Варшаві, які під час правління імператора Миколи I мали подвійні номінали у рублях, копійках, злотих та грошах. У колекції музею представлені рідкісні 3/4 рубля / 5 злотих 1838 року. Монети Олександра III, окрім обігових монет, зберегли й коммеморативні зразки рублів, які були випущені на честь коронації імператора у 1883 роичі.

У музейній збіриі найбільще російських імперських монет, щуо карбувалися у період правління останнього з династії Романових - імператора Миколи II. Саме вони поєднують, практично, весь номінальний ряд мідних та срібних монет. До спеціальної інвентарної книги було помилково внесено монету, у складі якої, за результатами проведеної апробації, не виявилося вмісту дорогоцінних металів. Із високим ступенем імовірності можна стверджувати, щзо даний виріб - тогочасна підробка монети. $B$ колекції музею зберігаються 70 дукачів, щзо походять з етнографічної зони Середньої Наддніпряншини (Полтавської, Чернігівської, Черкаської та Київської областей) $i$ можуть бути датовані кінием XVIII - початком XX століття.

У колекиії НІЕЗ «Переяслав» також збережено декілька скарбів. Це скарб півтораків Сигізмунда ІІІ Вази кількістю 291 монета та дротових копійок Московського царства часів Петра I кількістю 265 одиниць. Найбільш пізні монети, щзо збережені у колекиії НІЕ3 «Переяслав», - монети Радянського Союзу. Здебільшого ие срібні полтинники РСФСР зразка 1921-1922 років, рубль 1921 року, а також карбовані за часів НЕПу полтинники з образами «ковалів» 1924-1927 років.

Перспективою подальших досліджень ми вважаємо введення до наукового обігу нових надходжень нумізматичної колекції НІЕЗ «Переяслав» а також вивчення та введення до наукового обігу матеріалів із зібрань нумізматики інших музеїв України.

Разом із предметами нумізматики у фондовому сховищі музею також зберігаються предмети фалеристики: нагороди, медалі та відзнаки, які так само потребують окремого детального дослідження.

Ключові слова: НІЕ3 «Переяслав», колекція нумізматики, археологічні пошуки, Річ Посполита, «єфімок з признаком», тогочасні підробки, дукачі.

\section{Summary.}

The aim of the study is to introduce into the scientific circulation of the materials of the numismatic collection of NHER «Pereyaslav», to study it's structure and to identify the most interesting samples in the context of the history of Pereyaslav region coin. Research methodology. In the process of scientific study of the collection of the museum were used generally scientific methods: analytical, illustrative, chronological, typological, as well as source methods: critical, metrological and iconographic. The scientific novelty is in the first comprehensive study of the entire numismatic collection of the reservation that has been introduced into scientific circulation, as well as the data of the archeological finds of the Pereyaslav Region that have been included in the museum. The catalog (inventory list) published 
in the article will serve as an additional source for the researchers of the history of money circulation in Kyiv region.

The Conclusions. In the conditions of active distribution of the so-called «black archeology" with low reliability and often doubtfulness of the received data, with limited possibility of use in the numismatic researches, actual for modern numismatic science is the introduction into the scientific circulation and research of the museum collections. The numismatic collection of the museum was investigated quite fragmentarily: the researchers introduced counterfeit coins of the Polish-Lithuanian Commonwealth and the traditional women's jewelry "dukach», and the staff of the archaeological expedition of the museum regularly published the results of searches for perehodlavlav. The numismatics collection has more than 12,000 coins from the Roman Empire to the XX century. Some of the numismatics items are displaying in the exposition at the reserve's premises. Coins of the XVIIXVIII centuries, minted in Western Europe, Commonwealth and Muscovy are on display in the Museum Department of the Covenant.

During the last 20 years, the museum was receiving coins excavated by archaeologists in Pereyaslav: ancient coins of the Roman Empire, coins of the Kyiv principality, Byzantium and Polish-Lithuanian Commonwealth and it's vassal lands in the XVII century. The numismatic collection contains 47 thalers of Western Europe, which fully correspond to the specifics of the circulation of the region. The decoration of the museum collection is "efimok with signs» minted during the reform of Alexei Mikhailovich in 1655. A considerable part of the collection are the coins of the Russian Empire. The greatly interesting are the coins of Peter the Great-altinas, hryvnia, rare poltina and ruble of the ruler. Decorated with detailed portraits of the Russian Empresses Anna Ioannivna and Catherine the Great and the silver rubles of the 1730s are also presented in the museum's collection. Common on the Right Bank were coins minted in the Kingdoms of Poland at the Mint in Warsaw, which during the reign of Emperor Nicholas I had double denominations in rubles, kopecks, zloty and grosz. The museum's collection presents the rare $3 / 4$ rubles / 5 zloty coin minted in 1838. In addition to circulating coins, the Alexander III coins also preserved by commemorative rubles, issued in honor of the emperor's coronation in 1883.

Most of the Russian imperial coins in the museum collection were minted during the reign of the last emperor of the Romanov dynasty - Nicholas II, combining practically the entire nominal series of copper and silver coins. In the special inventory book was mistakenly entered a coin that, according to the results of the research, did not show the content of precious metals. It is highly probable that this is a product of a counterfeiters being made for the purpose of treat. The museum's collection contains 70 ducachs originating from the ethnographic zone of the Middle Dnieper region (Poltava, Chernihiv, Cherkasy and Kyiv regions), the products can be dated to the end of XVIII - the beginning of XX century.

The collection contains also several treasures. This are the treasure of one and a half grosz (poltorak) of Sigismund III Vasa in the amount of 291 coins, and the treasure of the wire kopecks of the Moscow Kingdom of the time of Peter I the Great in the amount of 265 pieces. The most recent coins kept in the collection are the coins of the Soviet Union. For the most part, these are the silver shades of the RSFSR of the sample of 1921-1922, the ruble of 1921, and also minted during the NEP the «blacksmiths» type of 1924-1927.

As the prospects of further research we see the introduction into the scientidic circulation of new additions to the numismatic collection, as well as to study and introduce into the circulation materials from collections of numismatics of other museums in Ukraine. In addition to the numismatics items, the museum's stockpile also houses items of phaleristics: awards, medals and insignia, which also require a separate detailed study. 
Keywords: NHER «Pereyaslav», numismatic collections, archeological researches, Polish-Lithuanian Commonwealth, "yefimok with signs», money counterfeits, "dukach» as the closes adornment.

Постановка проблеми. В умовах появи протягом минулих 20-ти років численної кількості матеріалів «чорної» археології, більша частина корисної для науки інформації щодо яких, зазвичай, стала безповоротно втраченою ${ }^{1}$, матеріали, збережені та зібрані співробітниками музеїв становлять надзвичайно цінне джерело вивчення, яке відзначається високим ступенем достовірності.

Вивчення фондових колекцій та їх публікацію ми визначали як один із актуальних напрямків досліджень у галузі середньовічної нумізматики в Україні².

У попередніх нумізматичних розвідках нами було введено до наукового обігу монети з колекції Національного Києво-Печерського історико-культурного заповідника Національного музею історії України та Дніпропетровського національного історичного музею ${ }^{4}$.

\section{Аналіз останніх досліджень i публікацій. Нумізматична колекція} HIE3 «Переяслав» була досліджена досить фрагментарно. Автором було введено у науковий обіг «єфімок $з$ признаком» 1655 року а також європейські крупні срібні монети - талери XVII століття ${ }^{6}$. Тогочасні підробки виготовлені за прототипом монет Сигізмунда III Вази (1587-1632), опубліковані А. Бойком-Гагаріним та А. Кузьменком . Традиційні жіночі прикраси народного святкового вбрання - «дукачі», 3 колекції опубліковано у працях І. Дунайної ${ }^{8}$ О. Юрченко ${ }^{9}$ та В. Нестеренко ${ }^{10}$. Археологом О. Прядко повідомлено про знахідку на території заповідника монет Римської імперії ${ }^{11}$, Київського князівства XIV століття ${ }^{12}$, монет Речі Посполитої та окупованих Швецією земель Балтії ${ }^{13}$. Співробітником заповідника Д. Тетерею введено у науковий обіг нове надходження до зібрання з місцевих археологічних знахідок - мідний анонімний фоліс Візантії ${ }^{14}$.

Теоретико-методологічні основи дослідження. У процесі наукового опрацювання колекції заповідника було використано загальнонаукові методи: аналітичний,

Kotsur V. Methodological issues of modern numismatic research: materials of «black» archeology and scientific research. Studia I Materialy «Forum Numizmatyczne, Pieniadz I Mennice». № 1. Bialystok, 2016. S. 5-9.

2 Коцур В. П. Актуальні напрямки та організаційні засади сучасних досліджень середньовічної нумізматики в Україні. Наукові записки 3 української історії: Збірник наукових статей. Вип. 33. Переяслав-Хмельницький, 2013. 222 с.

3 Коцур В. П. Португал Богемії з колекції Національного Києво-Печерського історико-культурного заповідника. Збірник тез доповідей V Міжнародної науково-практичної конференції «Актуальні питання нумізматики в системі спеціальних галузей історичної науки». (21 - 22 червня 2018 р.). Меджибіж-Переяслав-Хмельницький-Кропивницький-Київ, 2018. C. 89-90.

${ }^{4}$ Kotsur V., Boiko-Gagarin A. Napoleon russian forged assignations in Naddniprianshchyna (over Dnipro land). East European historical bulletin. Issue 11. Drohobych, 2019. P. 66-77.

${ }^{5}$ Коцур В.П. Єфімок з признаком у колекції Національного історико-етнографічного заповідника «Переяслав». Тези доповідей ІІІ Міжнародної науково-практичної конференції «Актуальні проблеми нумізматики у системі спеціальних галузей історичної науки», 5-6 листопада 2015 р. Кіровоград-Київ-Переяслав-Хмельницький, 2015. С. 59-60.

${ }^{6}$ Коцур В. П. Талеры и ефимок с признаками в коллекции Национального историко-культурного заповедника «Переяслав», как источник денежного обращения в Украине в XVI-XVIII веках. Acta Archaeologia Lodziensia. Nr 61. Lodz, 2016. P. 77-80.

Бойко-Гагарін А. С., Кузьменко А. В. Фальшиві монети часів Сигізмунда III Ваза у колекції НІЕЗ «Переяслав». 3б. наук. ст. «Переяславський літопис». Випуск 9. Переяслав-Хмельницький, 2016. С. 186-188.

8 Дунайна I. Г. Дукачі та лимани з колекції НІЕЗ «Переяслав». Переяславіка: Наукові записки НІЕЗ «Переяслав». Переяслав-Хмельницький, 2009. Вип. 3(5). С. 115-118.

9 Юрченко О. Дукач із с. Лецьки на Переяславщині. Наукові записки з української історії. Випуск 33. Переяслав-Хмельницький, 2013. С. 168169.

${ }^{10}$ Нестеренко В. І. Особливості золотарського ремесла Лівобережжя Черкащини (за фондовою колекцією дукачів). Переяславіка: Наукові записки НIЕ3 «Переяслав». Переяслав-Хмельницький, 2012. Вип. 6 (8). С. 187-197.

${ }^{11}$ Прядко О., Юрченко О. Нові знахідки римських монет на Переяславщині. Ніжинська Старовина. Серія Памяткознавство Північно-Східного регіону України. № 9. Випуск 24 (27). Ніжин-Київ, 2017. С. 84-91.

${ }_{12}$ Прядко О. Знахідка монети Володимира Ольгердовича XIV ст. 3 м. Переяслав. Нові дослідження пам'яток Козацької доби в Україні. Випуск 28. Київ, 2019. С. 125-126.

13 Прядко О., Юрченко О. Нумізматичні знахідки ранньомодерного часу з с. Пристроми на Переяславщині. Нові дослідження пам'яток Козацької доби в Україні. Випуск 24. Київ, 2015. С. 143-148.

${ }_{14}$ Тетеря Д., Прядко О. Знахідка візантійської монети на території Південно-Західної Переяславщини. Збірник праць IV Міжнародної науковопрактичної конференції «Актуальні проблеми нумізматики в системі допоміжних історичних дисциплін». $22-23$ червня 2016 р. Кіровоград-Київ-Переяслав-Хмельницький, 2016. С. 26-29. 
ілюстративний, хронологічний, типологічний, а також джерелознавчі методи: критичний, метрологічний та іконографічний ${ }^{1}$.

Формулювання цілей статті. Головна мета статті - введення до наукового обігу матеріалів нумізматичного зібрання HIE3 «Переяслав», вивчення його структури та виокремлення найбільш цікавих у контексті історії Переяславщини зразків монет.

\section{Виклад основного матеріалу дослідження. Колекція нумізматики} HIE3 «Переяслав» налічує більше 12.000 монет від Римської імперії до XX століття. Спеціальна інвентарна книга з обліку предметів нумізматики має шифр «СН» для таких, що містять у своєму складі дорогоцінні метали та каміння; для тих монет, які входять як складові основного фонду Переяслав-Хмельницького історичного музею вона має шифр «СД». Інвентарні номери за інвентарною книгою предметів колекції нумізматики та фалеристики мають позначення літерою «Н». Також предметам 3 музейного зібрання у фондово-обліковій документації присвоюється номер за книгою надходження або книгою вступу, що в заповіднику прийнято зазначати літерами «КВ» (наприклад: Монета копійка Олексія Михайловича, Московське царство. Інв. № Н-1359, КВ-12712).

Інвентарні книги музею 3 фондово-обліковою документацією призначені для внутрішнього користування у музеї. В той же час старі інвентарні книги можуть пролити світло на історію створення колекції 2 , надати змогу вивчити окремі епізоди формування та зберігання колекції ${ }^{3}$, отримати додаткові свідчення про окремі зразки колекції. Для виконання даного дослідження інвентарні книги, складені зберігачами музею, прислужилися для вивчення та формування структури нумізматичної колекції.

Частина предметів нумізматики нині експонується у приміщеннях заповідника. Монети XVII-XVIII століття, карбовані у Західній Європі, Речі Посполитій та Московії, експонуються у відділі «Музей Заповіту», жіночі прикраси для одягу - «дукачі», також експонуються у філії «Музею українських обрядів»4.

Знахідки античних монет відомі дослідникам на Правобережжі ${ }^{5}$ та Київщині 6 , зокрема у Переяславському районі. Дослідником О. Колибенком повідомляється про виявлення неподалік від сучасного села Натягайлівка борисфена античної Ольвії та передачу його до лабораторії археологічних досліджень при кафедрі історії та культури України ДВНЗ «Переяслав-Хмельницький державний педагогічний університет імені Григорія Сковороди» ${ }^{7}$, де з 1996 року функціонує Музей освіти та історії8.

Про знахідку двох монет Римської імперії на території скансену «Музею народної архітектури та побуту Середньої Наддніпрянщини» у 2013 році повідомляють О. Прядко та О. Юрченко9. Розвідками Археологічної експедиції Національного історикоетнографічного заповідника «Переяслав» виявлено денарії римських імператорів Луція Елія (100-138 рр. н.е.), Антоніна Пія (86-161 рр. Марка Луція Коммода (161-192 рр.) (Рис. 1).

\footnotetext{
Калакура Я. С., Войцехівська І. Н. Історичне джерелознавство. Підручник для студентів історичних спеціальностей вищих навчальних закладів. Київ: Либідь, 2002. С. 120.

Бойко-Гагарин А., Корпусова И. Монетно-вагові зливки гривні та їх тогочасні підробки з колекції Одеського археологічного музею. Записки отдела нумизматики и торевтики Одесского археологического музея. № III. Одесса: Ибрис, 2017. С. 120-132.

3 Орлик В., Бойко-Гагарін А. Монети, передані з Всеукраїнського Історичного Музею імені Тараса Шевченка до Державного Банку СРСР в 1933-1934 pp. Studia I materialy z Miedzynarodowej Konferencji Numizmatycznej. «Utracone kolekcje numizmatyczne». 6-7 grudnia 2018 r. Warszawa: Zamek Krolewski w Warszawie, 2019. S. 225-237.

4 Зубер С., Захарченко С. Музей українських обрядів НІЕЗ «Переяслав»: до історії започаткування та проведення народних свят. Жовківські читання 2011. Збірник статей першої наукової конференції «Музей в сучасному світі». Ливів: Растр-7, 2011. С. 88-91.

Орлик В., Коцур В., Цыганенко Л. 2019. Клад ольвийских монет «борисфенов», найденный в Городищенском районе Черкасской области весной 2018 года. Acta Archaeologica Lodziensia, 65, 37-48.

${ }^{6}$ Mielczarek, M., \& Orlyk, V. (2019). New find of Olbian coins. Tarashcha district, Kyiv region, Ukraine. Skhidnoievropeiskyi Istorychnyi Visnyk [East European Historical Bulletin], 13, 33-39. doi: 10.24919/2519-058x.13.190763

Колибенко О., Колибенко О. Знахідки ольвійських монет на Переяславщині. Збірник праць IV Міжнародної науково-практичної конференції «Актуальні проблеми нумізматики в системі допоміжних історичних дисциплін». 22-23 червня 2016 р. Кіровоград-Київ-ПереяславХмельницький, 2016. С. 18-21.

8 Демуз I. О. Музеї при закладах освіти Переяславщини. Переяславський літопис. Випуск 2. Переяслав-Хмельницький, 2011. С. 22-37.

9 Прядко О., Юрченко О. Нові знахідки римських монет на Переяславщині. Ніжинська Старовина. Серія Пам'яткаознавство Північно-Східного регіону України. № 9. Випуск 24 (27). Ніжин-Київ, 2017. С. 84-91.
} 
У колекції НІЕ3 «Переяслав» також наявна мідна монета Візантійської імперії. У 2012 році на околиці с. Пристроми Переяслав-Хмельницького району було знайдено мідний анонімний фоліс Візантії, який згодом був переданий до колекції заповідника. Фоліс належить до класу «В», карбований у період правління Романа III Аргір або Михайла IV (з 1030-1035-1042рp. ?). Ми підтримуємо позицію дослідників знахідки, Д. Тетері та О. Прядка, щодо свідчення вказаної знахідки про розвинені торгівельні відносини Переяславського князівства у період Давньої Русі ${ }^{1}$.

На території музею просто неба НІЕ3 «Переяслав»- «Музею народної архітектури та побуту Середньої Наддніпрянщини» - у 2017 році було виявлено монету Київського князівства рідкісного типу із зображенням «вузла щастя» на реверсі, карбовану за правління Володимира Ольгердовича у 80-90-х роках XIV століття².

Найбільша кількість серед збережених у НIE3 «Переяслав» монет належить до періоду карбування Речі Посполитої, їі васальних земель, курфюршества БранденбургПруссія та окупованих Швецією територій Балтії.

Своєрідний «зріз» характерних для грошового обігу Переяславщини XVIXVII століть особливостей демонструє комплекс монет, зібраних у 2009 році одним із мешканців с. Пристроми Переяслав-Хмельницького району Київської області та переданих до зібрання НIЕ3 «Переяслав» ${ }^{3}$. Нове надходження монет поєднувало півгроші Яна I Ольбрахта (1492-1501), Олександра Ягеллона (1501-1506) та Сигізмунда I Старого (1506-1545), московську дєньгу Івана IV Грозного (1533-1584), польсько-литовські монети Сигізмунда III Вази (1587-1632), монети Бранденбурга-Пруссії курфюрста Георга Вільгельма (1619-1640) а також соліди шведських королів Густава II Адольфа (16111632), його доньки Христини (1632-1654) та іï наступника Карла Х Густава (1654-1660), виготовлені на монетних дворах окупованих Швецією земель Балтії, та імітації за їх прототипом, виготовлених у Молдавському князівстві на монетному дворі м. Сучави.

Серед монет Речі Посполитої варто відмітити рідкісний зразок гроша, карбованого у 1577 році під час облоги Гданська (Інв. № H-3663, КВ-1413). Монети XVI століття представлені також і поширеними на ту пору у грошових розрахунках прусськими широкими грошами курфюрста Альбрехта Гогенцоллерна та грошами Сигізмунда I Старого, що були виготовлені на монетних дворах у Гданську та Вільно у Великому князівстві Литовському. У музеї монети литовського карбування, представлені поширеними півгрошами, збережено у вигляді зразків років найбільш чисельної емісії: 1547, 1548, 1549, 1550, 1551, 1552 та 1556 років (Н-3663-(1-92), КВ-1413).

Справжнього апогею у своєму розвиткові грошова система досягла у період правління у Речі Посполитій Сигізмунда III Ваза. У цю пору на українських землях в обігу перебуває небачена раніше кількість монетних номіналів, карбованих на численних монетних дворах. У колекції музею представлені у фондах та експозиції найбільш популярні монети дрібного та середнього номіналу, карбовані за часів монарха, особливо найбільш популярні гроші, півтораки, трояки, шостаки та орти (18 грошовики або 1/4 талерові монети). Схожими за стилем виконання з півтораками Речі Посполитої були драйпелькери курфюршества Бранденбург-Пруссія та карбовані шведами на монетних дворах в окупованих Ризі та Ельблонгу, які також у значній кількості представлені серед монет зібрання заповідника.

Тетеря Д., Прядко О. Знахідка візантійської монети на території Південно-Західної Переяславщини. Збірник праць IV Міжнародної науковопрактичної конференції «Актуальні проблеми нумізматики в системі допоміжних історичних дисциплін». $22-23$ червня 2016 р. Кіровоград-Київ-Переяслав-Хмельницький, 2016. С. 26-29.

2 Прядко О. Знахідка монети Володимира Ольгердовича XIV ст. з м. Переяслав. Нові дослідження пам’яток Козацької доби в Україні. Випуск 28. Київ, 2019. С. 125-126.

3 Прядко О., Юрченко О. Нумізматичні знахідки ранньомодерного часу з с. Пристроми на Переяславщині. Нові дослідження пам'яток Козацької доби в Україні. Випуск 24. Київ, 2015. С. 143-148. 
Серед наявних у фондах НIЕ3 «Переяслав» монет Сигізмунда III Ваза (1586-1632) дослідниками А. Бойком-Гагаріним та А. Кузьменком виявлено три тогочасні підробки, виготовлені у XVII столітті для отримання за рахунок їх збуту незаконних прибутків. Монетні фальсифікати зберігаються в одному пакеті з близько 100 монетами Сигізмунда III Вази (Інв. № ПХІМ КВ-285, Н-534). Монети виготовлені з міді, поверхневий шар білого металу втрачений, стилістично елементи зображення скопійовані фальшивомонетниками на досить примітивному рівні. Підробки імітують півтора гроша 1619-1627 років та дрібні соліди за прототипами карбованих на монетному дворі у м. Ризі ${ }^{1}$.

Монети Речі Посполитої другої половини XVII століття представлені у меншій кількості шостаком 1683 року короля Яна III Собеського (Н-37, КВ-2807) та нечастими півтораками 1662 року (Н-565, КВ-4513) і 1666 року (Н-38, КВ-2807) короля Яна II Казимира.

Дорогі та значні торгові угоди реалізувалися за допомогою великогабаритної срібної монети вагою 28 грам - талера, яка карбувалась емітентами майже усієї Європи за єдиним стандартом якості металу та ваги.

Переважна більшість талерів та дукатів, знайдених у скарбах України, левендаальдери Об'єднаних провінцій Нідерландів, які внаслідок торгівлі поширились по всій Східній Свропі. Саме через високу популярність талерова ${ }^{2}$ та дукатова ${ }^{3}$ монети також підроблялись фальшивомонетниками. У другій половині XVII століття левендаальдери обмінювались за курсовим співвідношенням на 60 литовських або 75 польських грошів ${ }^{4}$. У скарбах також фігурують флорини, зільбердукати, альбертусталери та ріксдаальдери ${ }^{5}$.

У нумізматичній колекції НIE3 «Переяслав» збережено 47 талерів, які повністю відповідають специфіці грошового обігу регіону. У зібранні також зберігається талер архієпископства Зальцбург та швейцарського кантону Сент-Галлен ${ }^{6}$.

В описі до нумізматичної колекції заповідника мають місце й певні неточності: в інвентарній книзі вказано на наявність талера Речі Посполитої, карбованому від імені Августа III Сильного у 1754 році, хоча насправді зазначена монета - орт (Рис. 2)7.

Найбільш поширеними монетами, карбованими у Московському царстві, були дрібні дротові копійки, карбовані за правління Олексія Михайловича (1645-1676) (Н-2133-(1-4), КВ-278) та Федора Олексійовича (1676-1682) (Н-2133, КВ-278).

Окрасою музейної колекції став карбований за часів реформи Олексія Михайловича «єфімок 3 признаком» 1655 року. Справжні московські «єфімки 3 признаком» - це західноєвропейські талери з нанесеними на їх поле двома наддруками штемпелем московської копійки царя Олексія Михайловича та другого клейма у вигляді дати - «1655». Саме такий справжній автентичний «єфімок з признаком» із зібрання НIE3 «Переяслав» висвітлений нами у попередніх дослідженнях ${ }^{8}$ (Рис. 3).

Представлений у колекції музею «єфімок 3 признаком» - це левендаальдер міста Гельдерн 1620-их років, на поле реверсу якого нанесено контрамарку штемепелм московської копійки Олексія Михайловича9.

\footnotetext{
Бойко-Гагарін А. С., Кузьменко А. В. Фальшиві монети часів Сигізмунда III Ваза у колекції НІЕЗ «Переяслав». 3б. наук. ст. «Переяславський літопис». Випуск 9. Переяслав-Хмельницький, 2016. С. 186-188.

2 Бойко-Гагарин А. С. Фальшивый венгерский талер 1580 года. Нумизматика и Фалеристика. №1. 2015. С. 8.

3 Orlyk, W. Falszywy dukat lenny z 1588 roku odkryty na Ukrainie. Przeglad Numizmatyczny. - Gdansk, 2014. - № 3 (86). - S. 48.

${ }^{4}$ Бакалець О. А. Талер в грошовому обігу України кінця XVI - першої чверті XVIII ст. Бар, 2004. C. 11.

${ }^{5}$ Котляр М. Ф. Грошовий обіг на території України доби Феодалізму. Киев, 1971.

${ }^{6}$ Коцур В. П. Талеры и ефимок с признаками в коллекции Национального историко-культурного заповедника «Переяслав», как источник денежного обращения в Украине в XVI-XVIII веках. Acta Archaeologia Lodziensia. Nr 61. Lodz, 2016. P. 77-80.

7 HIE3 «Переяслав» - №2131/КВ-278

${ }^{8}$ Коцур В. П. Талеры и ефимок с признаками в коллекции Национального историко-культурного заповедника «Переяслав», как источник денежного обращения в Украине в XVI-XVIII веках. Acta Archaeologia Lodziensia. Nr 61. Lodz, 2016. P. 77-80.

Спасский И. Г. Каталог ефимков 1655 г. Нумизматика и Сфрагистика. Т. 4, Киев, 1971. С. 102-103.
} 
Досить значну за кількістю частину колекції займають монети Російської імперії. Особливу цікавість представляють монети Петра I - алтини, гривеники, рідкісні полтини та рублі правителя. Також у колекції музею представлені прикрашені деталізованими портретами російських імператриць Ганни Іоанівни та Катерини I срібні рублі 1730-их років (Рис. 4). Представлені монети використовувалися у процесі грошового обігу, оподаткування та фінансових розрахунків у Гетьманщині ${ }^{1}$.

Найбільше російських імперських монет музейної збірки карбовані у XIX столітті та в період правління останнього імператора 3 династії Романових - Миколи II. Таким чином поєднався, практично, весь номінальний ряд мідних та срібних монет. Монети Російської імперії демонструють значний розвиток фінансів у державі², засвідчують грошові відносини місцевого населення ${ }^{3}$ а також виступають інструментами оплати податків і зборів ${ }^{4}$, частина яких у першій половині XIX століття у Київській, Подільській та Волинській губерніях зберігалась ще з часу Речі Посполитої5. На Правобережжі були поширеними монети, карбовані у Царстві Польському на монетному дворі у Варшаві, які пртягом періоду правління імператора Миколи I мали подвійні номінали у рублях, копійках, злотих та грошах. У колекції музею представлені рідкісні $3 / 4$ рубля / 5 злотих 1838 року (Н-601, КВ-4826). Монети Олександра III, окрім обігових монет, зберегли i коммеморативні зразки рублів, випущені на честь коронації імператора у 1883 році (H-602, KB-4827).

До спеціальної інвентарної книги помилково було внесено монету, в складі якої за результатами проведеної апробації не виявилося вмісту дорогоцінних металів (Російська імперія. Монета 20 копійок. 1912 р. Інв. № Н-596, КВ-4755.). 3 високим ступенем імовірності цей виріб - тогочасна підробка монети 6 .

Монети Російської імперії в Україні мали і таке традиційне застосування розміщені в оправі з бантом з інкрустованим камінням на разок коралового намиста вони перетворювалися на «дукачі». Жіночі прикраси з використанням монет Російської імперії, які зберігаються в колекції HIE3 «Переяслав», опубліковано у працях I. Дунайної7. Дослідниця фіксує в колекції музею 70 дукачів (Рис. 5), що походять з етнографічної зони Середньої Наддніпрянщини (Полтавської, Чернігівської, Черкаської та Київської областей). Дані вироби можуть бути датовані кінцем XVIII - початком XX століття. Крім окремих дукачів у заповіднику наявні також намиста з монетами. Намисто з 11 монет із села Великий Байрак, що на Полтавщині (Т-3930, КВ-5093), експонується у музеї та його філіях у Переяславі. Більшість дукачів, за даними дослідниці, походять із самого Переяслава і були знайдені під час експедицій, закуплені чи отримані в подарунок від місцевих мешканців. Дослідник О. Юрченко вводить до наукового обігу дукач останньої

\footnotetext{
${ }^{1}$ Орлик В. М. Фіскальний апарат Гетьманщини (1654-1764рр.). Бористен, 2010. №8. С. 25-28.

2 Орлик В. М. Державні фінанси Російської імперії першої половини ХІХ ст.: стан та основні тенденції. Науковий вісник Ізмаїльського державного гуманітарного університету. Вип. 30. Ізмаїл, 2011. С. 96-108.

${ }^{3}$ Орлик В. М. Козацтво Лівобережної України у фінансовій політиці Російської імперії у кінці XVIII - середині XIX ст. Проблеми історії України XIX - початку XX ст. Вип. XVI. Київ: Ін-т історії України НАН України, 2009. С. 83-97;

${ }^{4}$ Орлик В.М. Податкова політика Російської імперії в Україні в дореформений період: монографія. Кіровоград: Імекс-ЛТД, 2007. 631 с. Його ж. Орлик В. М. (2007). Селянство України в фіскальній політиці імперій Романових і Габсбургів. Проблеми історії України ХІХ - початку ХХ ст. Вип.13. С. 83-86. Його ж. Орлик В. М. Єгор Канкрін і фіскальна політика Російської імперії в Правобережній Україні в другій чверті ХІХ ст. Спеціальні історичні дисципліни: питання теорії та методики. 2006. № 13. С. 97-110. Його ж. Орлик В. М. Проблеми історії податкової політики Російської імперії в українському селі кінця XVIII - початку XX ст. в «аграрній» історіографії. Історія України. Маловідомі імена, події, факти. (Збірник статей). Випуск 27. К.: Інститут історії НАН України, 2004. С.224-239.

5 Орлик, В. М. Регіональні особливості податкової політики уряду Російської імперії в дореформений період: проблеми методології дослідження. Гуржіївські історичні читання : зб. наук. пр. Черкаси, 2011. Вип. 4. С. 281-283.

${ }^{6}$ Бойко-Гагарін А. С. Газетна періодика як джерело вивчення процесів фальшування монет та банкнот в кінці XIX - початку XX століття. Український нумізматичний щорічник. № 2. Переяслав-Хмельницький, 2018. С. 132-149. Також. Орлик, С. В. \& Бойко-Гагарін, А. С. Фальшивомонетництво в Україні в роки Першої світової війни. Український нумізматичний щорічник. №1. Київ, 2017. С. 143-164. БойкоГагарин А. С. Фальшивомонетничество в Центральной и Восточной Европе в эпоху Средневековья и раннего Нового времени. Киев: Украинская конфедерация журналистов, 2017. С. 344-345.

7 Дунайна І. Г. Дукачі та лимани 3 колекції НІЕЗ «Переяслав». Переяславіка: Наукові записки НІЕ3 «Переяслав». Переяслав-Хмельницький, 2009. Вип. 3(5). С. 115-118.
} 
чверті XVIII століття, знайдений у 2012 році на околиці с. Лецьки ПереяславХмельницького району місцевою мешканкою О.I. Канівець. Методом аналогій дослідник співставив знахідку із аналогічним дукачем 3 колекції НIЕ3 «Переяслав» .

Найбільш пізніми монетами, що зберігаються у колекції НIE3 «Переяслав», стали монети Радянського Союзу. Здебільшого це срібні полтинники РРФСР зразка 19211922 років, рубль 1921 року, а також карбовані за часів НЕПу полтинники із зображенням «ковалів» 1924-1927 років.

Нумізматична колекція заповідника має також у своєму складі пам'ятні медалі, більшість яких експонувалася з 15 вересня до 1 грудня 2018 р. на виставці «Скарби НIЕ3 «Переяслав» у філії «Музей М.М. Бенардоса».

Вивчення та детальний аналіз скарбів - один з ефективних інструментів уточнення окремих питань метрології монет, систем їх лічби, що в попередніх дослідженнях ми визначали як один із актуальних напрямків сучасних досліджень із нумізматики, а саме доби Середньовіччя в історії українських історичних регіонів ${ }^{2}$.

Сукупність знань щодо монетних скарбів, зокрема джерелознавча цінність монетних комплексів, їх класифікація, причини тезаврації, топографія знахідок, склад скарбів, скарбові ємності, методологія та джерела дослідження, визначається поняттям скарбознавство, перспективи розвитку якого також визначалися нами у введенні до наукового обігу скарбів, що зберігаються у фондах державних та приватних музеїв, вивченні історії потрапляння скарбів до державних музеїв України, їх походження та історію вивчення ${ }^{3}$. Висока наукова інформативність та актуальність уведення скарбів до наукового обігу доведена у працях професора В. Орлика на прикладі монет Ольвії Тевтонського Ордену у Пруссії 5 . У колекції НIЕ3 «Переяслав» також зберігається декілька скарбів. Це скарб півтораків Сигізмунда III Ваза кількістю 291 монета (Н-544-(291), КВ-2851) та дротових копійок Московського царства часів Петра I кількістю 265 одиниць (2262 (1-265), КВ-290).

Висновки дослідження. В умовах активного поширення т. зв. «чорної археології» 3 ïi низькою достовірністю та часто сумнівністю отримуваних даних, 3 обмеженою можливістю використання знахідок у нумізматичних дослідженнях актуальним для сучасної нумізматичної науки стало введення до наукового обігу та дослідження музейних колекцій. Нумізматична колекція HIE3 «Переяслав» була досліджена досить фрагментарно: дослідниками введено в науковий обіг фальшиві монети Речі Посполитої та традиційні жіночі прикраси «дукачі», співробітниками археологічної експедиції музею регулярно публікувались результати пошуків на Переяславщині та нові надходження знахідок до музею. Колекція нумізматики НIE3 «Переяслав» налічує більше 12.000 монет, починаючи від Римської імперії до XX століття. Частина предметів нумізматики на сьогодні експонується у приміщеннях заповідника. Монети XVII-XVIII століть, карбовані у Західній Свропі, Речі Посполитій та Московії, експонуються у відділі «Музей Заповіту», жіночі прикраси для одягу - «дукачі», також експонуються у філії «Музей українських обрядів». До музею за останні 20 років надійшли монети, знайдені археологами на Переяславщині: античні монети Римської імперії, монети Київського князівства, Візантії, Речі Посполитої та її васальних у XVII столітті земель. У нумізматичній колекції НIE3

Юрченко О. Дукач із с. Лецьки на Переяславщині. Наукові записки з української історії. Випуск 33. Переяслав-Хмельницький, 2013. С. 168169.

Коцур В. П. Актуальні напрямки та організаційні засади сучасних досліджень середньовічної нумізматики в Україні. Збірник наукових статей «Наукові записки з української історії». Вип. 33. Переяслав-Хмельницький, 2013. С. 4.

Коцур В. П. Історіографія українського скарбознавства. Український Нумізматичний Щорічник. № 1. Київ-Переяслав-ХмельницькийКропивницький, 2017. С. 15-33.

${ }^{4}$ Орлик В. Скарб ольвійських «борисфенів» із с. Яселка Очаківського району Миколаївської області. Актуальні проблеми нумізматики у системі спеціальних галузей історичної науки: тези доповідей V-ї міжнародної науково-практичної конференції, 21-22 червня 2018 р. МеджибіжПереяслав-Хмельницький-Кропивницький-Київ, 2018.

Orlyk V. A Coin Hoard of Pre-Reform Shillings of the Grand Master Michael Küchmeister von Sternberg Found in Chernihivschyna. Acta Archaeologica Lodziensia, 62, 2016. S. 93-97. 
«Переяслав» збережено 47 талерів Західної Свропи, які повністю відповідають специфіці грошового обігу регіону. Окрасою музейної колекції став карбований за часів реформи Олексія Михайловича «єфімок з признаком» 1655 року. Досить значну за кількістю частину колекції займають монети Російської імперії. Особливу цікавість становлять монети Петра I - алтини, гривеники, рідкісні полтини та рублі правителя. Також у колекції музею представлені срібні рублі 1730-х років, що прикрашені деталізованими портретами російських імператриць - Ганни Іоанівни та Катерини I. На Правобережжі були поширеними монети, карбовані у Царстві Польському на монетному дворі у Варшаві, що в період правління імператора Миколи I мали подвійні номінали у рублях, копійках, злотих та грошах. У колекції музею представлені рідкісні 3/4 рубля / 5 злотих 1838 року. Монети Олександра III, окрім обігових монет, зберегли і коммеморативні зразки рублів, випущені на честь коронації імператора у 1883 році.

Найбільше російських імперських монет музейної збірки були карбовані протягом періоду правління останнього з династії Романових - імператора Миколи II. Таким чином поєднався, практично, весь номінальний ряд мідних та срібних монет. До спеціальної інвентарної книги помилково було внесено монету, у складі якої за результатами проведеної апробації не виявилося вмісту дорогоцінних металів. 3 високим ступенем імовірності цей виріб - тогочасна підробка монети.

У колекції музею зберігаються 70 дукачів, що походять 3 етнографічної зони Середньої Наддніпрянщини (Полтавської, Чернігівської, Черкаської та Київської областей), вироби можуть бути датовані кінцем XVIII - початком XX століття.

У колекції НIЕ3 «Переяслав» також збережено декілька скарбів. Це скарб півтораків Сигізмунда III Ваза кількістю 291 монета та дротових копійок Московського царства часів Петра I кількостю 265 одиниць. Найбільш пізніми монетами, збереженими у колекції НІЕЗ «Переяслав», стали монети Радянського Союзу. Здебільшого це срібні полтинники РРФСР зразка 1921-1922 років, рубль 1921 року, а також карбовані за часів НЕПу полтинники із зображенням «ковалів» 1924-1927 років.

Перспективою подальших досліджень ми бачимо введення до наукового обігу нових надходжень нумізматичної колекції HIE3 «Переяслав», а також вивчення та введення у науковий обіг матеріалів із зібрань нумізматики інших музеїв України.

Разом із предметами нумізматики у фондовому сховищі музею зберігаються також предмети фалеристики: нагороди, медалі та знаки, які так само потребують окремого детального дослідження.

\section{Каталог}

Інвентарний список нумізматичної колекції НIE3 «Переяслав»

\begin{tabular}{|c|c|c|c|c|}
\hline $\begin{array}{c}\text { № } \\
n / n\end{array}$ & Iнв. № $\mathrm{H}$ - & $\begin{array}{c}\text { Книга } \\
\text { надход- } \\
\text { жень }\end{array}$ & $\begin{array}{c}\text { Назва } \\
\text { та короткий опис предмета }\end{array}$ & 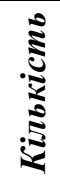 \\
\hline 1. & 4372 & & Монета 50 коп., РРФСР, 1922 р. & 1 \\
\hline 2. & 3512 & KB-1267 & Монета 1 крб, Росія, Петро II, 1727 р. & 1 \\
\hline 3. & 3523 & KB-1278 & Монета 1 крб, Росія, Микола II, 1899 р. & 1 \\
\hline 4. & $3523-(1-2)$ & KB-1278 & Монета 1 крб, Росія, Олександр I, 1812 р.-1 шт., 1815 р.-1 шт. & 2 \\
\hline 5. & 3523 & KB-1278 & Монета 1 крб, Росія, Микола I, 1829 р. & 1 \\
\hline 6. & 3523 & KB-1278 & Монета 1 крб, Росія, Микола I, 1846 р. & 1 \\
\hline 7. & 3524 & KB-1279 & Монета 50 коп., Росія, Микола II, 1895 р. & 1 \\
\hline 8. & 3525 & KB-1280 & Монета 25 коп., Росія, Олександр III, 1891 p. & 1 \\
\hline
\end{tabular}




\begin{tabular}{|c|c|c|c|c|}
\hline $\begin{array}{l}\text { No } \\
n / n\end{array}$ & Інв. № $\mathrm{H}$ - & $\begin{array}{c}\text { Книга } \\
\text { надход- } \\
\text { жень }\end{array}$ & $\begin{array}{c}\text { Назва } \\
\text { та короткий опис предмета }\end{array}$ & 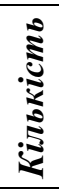 \\
\hline 9. & 3526 & KB-1281 & "Монета 5 коп., Росія, Олександр I, 1823 р. & 1 \\
\hline 10. & $3526-(1-3)$ & КВ-1281 & $\begin{array}{l}\text { Монета } 15 \text { коп., Росія, Микола II, } 1902 \text { р.-1 шт., } 1906 \text { р. -1шт., } \\
1915 \text { р.-1 шт. }\end{array}$ & 3 \\
\hline 11. & $3526-(1-11)$ & KB-1281 & $\begin{array}{l}\text { Монета } 10 \text { коп., Росія Микола II, 1903-1, 1910-1, 1913-1, 1914- } \\
\text { 2, 1915-6 }\end{array}$ & 11 \\
\hline 12. & $3526-(1-5)$ & KB-1281 & Монета 20 коп., Росія, Микола II, 1902 р.-1, 1914 р.-2,1915 р.-2 & 5 \\
\hline 13. & $3663-(1-6)$ & KB-1413 & $\begin{array}{l}\text { Монета грош пруський, Польща-Прусія, Сигізмунд I, } \\
1520 \text { р.-1,1530 р.-2, } 1531 \text { р.-1, } 1532 \text { р.-2 }\end{array}$ & 6 \\
\hline 14. & 3663 & КВ-1413 & $\begin{array}{l}\text { Монета полугрош, Польща, Казимир ІУ Ягеллончик, } \\
\text { 1447-1492 pp. }\end{array}$ & 1 \\
\hline 15. & $3663-(1-8)$ & KB-1413 & $\begin{array}{l}\text { Монета полугрош коронний, Польща, Сигізмунд I, 1508-3, } \\
1509 \text { р.-3, } 1510 \text { р.-2 }\end{array}$ & 8 \\
\hline 16. & 3663 & КВ-1413 & $\begin{array}{l}\text { Монета полугрош коронний, Польща, Олександр Ягеллончик, } \\
\text { 1501-1506 рр. }\end{array}$ & 5 \\
\hline 17. & 3663 & КВ-1413 & $\begin{array}{l}\text { Монета полугрош свидницький, Німецька імперія, Людвік II } \\
\text { Ягеллончик, 1506-1562 pp. }\end{array}$ & 2 \\
\hline 18. & 3663 & KB-1413 & $\begin{array}{l}\text { ояк литовський, Велике князівство Литовське, } \\
\text { II Август, } 1562 \text { р. }\end{array}$ & 1 \\
\hline 19. & 3663 & KB-1413 & Монета грош коронний, Річ Посполита, Сигізмунд III, 1624. & 1 \\
\hline 20. & 3663 & КВ-1413 & $\begin{array}{l}\text { Монета грош гданський, Річ Посполита, Стефан Баторій, } \\
1577 \text { р. }\end{array}$ & 1 \\
\hline 21. & 3663 & КВ-1413 & $\begin{array}{l}\text { Монета грош литовський, Велике князівство Литовське, } \\
\text { Сигізмунд I, } 1539 \text { р. }\end{array}$ & 1 \\
\hline 22. & $3663-(1-3)$ & KB-1413 & $\begin{array}{l}\text { Монета грош ельбінгський, Польща, Сигізмунд I, } \\
1533 \text { р., } 1539 \text { р., } 1540 \text { p. }\end{array}$ & 3 \\
\hline 23. & $3663-(1-3)$ & KB-1413 & Монета грош, Польща, Сигізмунд I, 1527 р.-шт., 1546 р.-2 шт. & 3 \\
\hline 24. & 3663 & KB-1413 & Монета грош гданський, Польща, Сигізмунд I, 1535 р. & 1 \\
\hline 25. & $3663-(1-2)$ & KB-1413 & Монета, Німецька імперія, Генріх Юлій, 1546, 1550 рр. & 2 \\
\hline 26. & $3663-(1-3)$ & KB-1413 & $\begin{array}{l}\text { Монета грош пруський, Прусія, Альберт Бранденбурзький, } \\
1545 \text { р.-2 шт., } 1547 \text { р.-1 шт. }\end{array}$ & 3 \\
\hline 27. & $3663-(1-6)$ & KB-1413 & $\begin{array}{l}\text { Монета подвійний денарій, Велике князівство Литовське, } \\
\text { Сигізмунд II, } 1570 \text { р.-4 шт., 1567р.-1 шт., } 1578 \text { р.-1 шт. }\end{array}$ & 6 \\
\hline 28. & $3663-(1-6)$ & KB-1413 & $\begin{array}{l}\text { Монета трояк литовський, Річ Посполита, Сигізмунд III, } \\
159 . ? \text { р.-1 шт., } 1592 \text { р.-1 шт., } 1593 \text { р.-1 шт., } 1594 \text { р.-2 шт., } \\
1595 \text { р.-1 шт. }\end{array}$ & 6 \\
\hline 29. & $3663-(1-92)$ & KB-1413 & $\begin{array}{l}\text { Монета полугрош литовський, Велике князівство Литовське, } \\
\text { Сигізмунд II, } 1547 \text { р.-7 шт., } 1548 \text { р.-6 ш., } 1549 \text { р.-5 шт., } 1550 \text { р.- } \\
2 \text { шт., } 155 . . ? \text { p.-1 шт., } 1552 \text { p.-1, } 1553 \text { p.-1, } 1556 \text { p.-3, } 1557 \text { p.-5, } \\
1558 \text { p.-5, } 1559 \text { p.-12 шт., } 1560 \text { p.-8, } 1561 \text { p.-12, } 1562 \text { p.-4, } 1563 \\
\text { p.-3, } 1564 \text { p.-8, } 1565 \text { p.-9 шт. }\end{array}$ & 92 \\
\hline 30. & $3663-(1-9)$ & KB-1413 & $\begin{array}{l}\text { Монета трояк ризький, Річ Посполита, Сигізмунд III, } \\
1592 \text { р.-4 шт., } 1594 \text { р.-3 шт., } 1595 \text { р.-2 шт. }\end{array}$ & 9 \\
\hline 31. & 3663 & $\mathrm{~KB}$ & $\begin{array}{l}\text { Монета грош литовський, Польща, Сигізмунд II Август, } \\
1547 \text { р. }\end{array}$ & 1 \\
\hline 32. & $4443-1,2$ & KB-2534 & Монета грош, Прусія, 1533,1535 рр. & 2 \\
\hline 33. & 4 & $\mathrm{~K}$ & $\begin{array}{l}\text { Монета півторак коронний, Швеція, Густав II Адольф, } \\
\text { 1621-1632 рр. }\end{array}$ & 1 \\
\hline 34. & 4445 & KB-2536 & Монета полугрош, Річ Посполита, Олександр Ягеллончик, ...? & 1 \\
\hline 35. & 4572 & KB-2655 & Монета 50 коп., РСФСР, 1922 р. & 1 \\
\hline
\end{tabular}




\begin{tabular}{|c|c|c|c|c|}
\hline $\begin{array}{l}\text { No } \\
n / n\end{array}$ & Інв. № $\mathrm{H}$ - & $\begin{array}{c}\text { Книга } \\
\text { надход- } \\
\text { жень }\end{array}$ & $\begin{array}{c}\text { Назва } \\
\text { та короткий опис предмета }\end{array}$ & 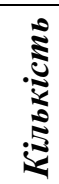 \\
\hline 36. & $2134(1-15)$ & KB-278 & Монета 1 коп. Росія, Петро I, ХУІІ ст. & 15 \\
\hline 37. & 2131 & КB-278 & $\begin{array}{l}\text { Монета 6-грошовик коронний, Річ Посполита, Сигізмунд III, } \\
1625 \text { р. }\end{array}$ & 1 \\
\hline 38. & 2131 & KB-278 & Монета орт, Річ Посполита, Август III, 1754 р. & 1 \\
\hline 39. & $2131-1-2$ & КВ-278 & $\begin{array}{l}\text { I монета - полугрош, Польща, Сигізмунд II Август, } 1560 \text { p.; } \\
\text { II монета - солід, Річ Посполита, Сигізмунд III, } 1625 \text { p. }\end{array}$ & 2 \\
\hline 40. & 2131 & KB-278 & Монета півгрош, Польща, Сигізмунд I Старий, 1517 р. & 1 \\
\hline 41. & $2131-(1-5)$ & KB-278 & Монета півторак, Річ Посполита, Сигізмунд III, 162..? & 5 \\
\hline 42. & 2132 & КB-278 & $\begin{array}{l}\text { Монета «єфімок з ознаками», Росія, Олексій Михайлович, } \\
1655 \text { р. }\end{array}$ & 1 \\
\hline 43. & 2131 & KB-278 & Монета орт гданський, Річ Посполита, Сигізмунд III, 1615 p. & 1 \\
\hline 44. & 2131-(1-4) & KB-278 & $\begin{array}{l}\text { Монета 6-грошовик коронний, Річ Посполита, Сигізмунд III, } \\
1623 \text { р.-1 шт., } 1624 \text { р.-1 шт., } 1625 \text { р.-1 шт., } 1627 \text { р.-1 шт. }\end{array}$ & 4 \\
\hline 45. & 2131 & КB-278 & $\begin{array}{l}\text { Монета 3-грошовик коронний, Річ Посполита, Сигізмунд III, } \\
1623 \text { р. }\end{array}$ & 1 \\
\hline 46. & $2131-(1-6)$ & КВ-278 & $\begin{array}{l}\text { Монета півторак коронний, Річ Посполита, Сигізмунд III, } \\
1620 \text { р.-1 шт., } 1622 \text { р.-1 шт., } 1623 \text { р.-4 шт. }\end{array}$ & 6 \\
\hline 47. & $2133-(1-4)$ & $3-278$ & Монета копійка, Росія, Олексій Михайлович, 1645-1676 pp. & 4 \\
\hline 48. & 2133 & KB-278 & копійка, $\mathrm{F}$ & 1 \\
\hline 49. & $\mathrm{H}-31$ & B-2807 & , Нідерл & 1 \\
\hline 50. & $\mathrm{H}-32$ & $\mathrm{~B}-2807$ & дерланди & 1 \\
\hline 51. & $\mathrm{H}-35$ & -2807 & $\mathrm{I}, 1622 \mathrm{p}$. & 1 \\
\hline 52. & $\mathrm{H}-37$ & $3-2807$ & HH III, $1683 \mathrm{p.}$ & 1 \\
\hline 53. & $\mathrm{H}-38$ & -2807 & $1666 \mathrm{p}$. & 1 \\
\hline 54. & $\mathrm{H}-39-1,2$ & $3-2807$ & 1616 p., $162 . ? \mathrm{p}$ & 2 \\
\hline 55. & $\mathrm{H}-40-1,2$ & $3-2807$ & льм, 1623, 1624 рр. & 2 \\
\hline 56. & H-43-(1-48) & $3-2807$ & -Литва, Сигізмунд III, 1621-1624 pp. & 48 \\
\hline 57. & H-44-(1-21) & KB-2807 & , Сигізмунд III, 1623-1626 pp. & 21 \\
\hline 58. & $\mathrm{H}-45$ & KB-2807 & півталер брабантський, Нідерланди, Філіп IУ, 1644 р. & 1 \\
\hline 59. & $\mathrm{H}-48-(1-8)$ & KB-2807 & $\begin{array}{l}\mathrm{MoH} \\
1629\end{array}$ & 8 \\
\hline 60. & H-47-(1-39) & KB-2807 & $\begin{array}{l}\text { Монета півторак, Прусія? Георг Вільгельм, } 162 . ? \text { р.-4 шт., } 1621 \\
\text { p.-2 шт., } 1622 \text { р.-3 шт., } 1623 \text { р.-6 шт., } 1624 \text { р.-11 шт., } 1625 \text { р.- } \\
2 \text { шт., } 1626 \text { р.-9 шт., } 1627 \text { р.-1 шт., } 1631 \text { р.-1 шт. }\end{array}$ & 39 \\
\hline 61. & H-49-(1-15) & KB-2807 & $\begin{array}{l}\text { Монета півторак, Швеція? Густав Адольф, } 1622 \text { р.-3 шт., } \\
1623 \text { р.-1 шт., } 1624 \text { р.-7 шт., } 1630 \text { р.-3 шт., } 1635 \text { р.-1 шт. }\end{array}$ & 15 \\
\hline 62. & H-50-(1-6) & KB-2807 & $\begin{array}{l}\text { Монета півторак, Швеція?, Густав Адольф, 163.? р.-4 шт., } \\
1631 \text { р.-2 шт. }\end{array}$ & 6 \\
\hline 63. & H-51(1-4) & KB-2807 & $\begin{array}{l}\text { Монета півторак, Швеція, Христина, } 1646 \text { р.-1 шт., } 1648 \text { р.- } \\
\text { Зшт. }\end{array}$ & 4 \\
\hline 64. & H-52(1-6) & KB-2807 & $\begin{array}{l}\text { Монета півторак, Швеція Христина, } 1635 \text { р.-1 шт., } 1644 \text { р.- } \\
2 \text { шт., } 1648 \text { р.-3 шт. }\end{array}$ & 6 \\
\hline 65. & $\begin{array}{l}\text { H-34-(1- } \\
369)\end{array}$ & KB-2807 & $\begin{array}{l}\text { Монета півторак коронний, Річ Посполита, Сигізмунд III, } \\
\text { ХУІІ ст. }\end{array}$ & $\begin{array}{c}36 \\
9\end{array}$ \\
\hline 66. & $\begin{array}{c}\text { H-36-(1- } \\
165)\end{array}$ & KB-2807 & $\begin{array}{l}\text { Монета 6-грошовик коронний, Річ Посполита, Сигізмунд III, } \\
\text { 20-і - 30-і рр. ХУІІ ст. }\end{array}$ & $\begin{array}{c}16 \\
5\end{array}$ \\
\hline 67. & $\mathrm{H}$ & 2807 & $\begin{array}{l}\text { Монета півторак коронний, Річ Посполита, Сигізмунд III, } \\
1623 \text { р. }\end{array}$ & 86 \\
\hline 68. & $\mathrm{H}-$ & KB-2807 & $\begin{array}{l}\text { Монета 6-грошовик коронний, Річ Посполита, Сигізмунд III, } \\
1625 \text { р. }\end{array}$ & 87 \\
\hline 69. & H-41-(1-4) & KB-2807 & $\begin{array}{l}\text { Монета талер брабанський, Нідерланди, Філіп ІУ, } \\
1623 \text { р.-1 шт., } 1636 \text { р.-1 шт., } 1654 \text { р.-1 шт., } 1655 \text { р.-1 шт. }\end{array}$ & 4 \\
\hline
\end{tabular}




\begin{tabular}{|c|c|c|c|c|}
\hline $\begin{array}{l}\text { No } \\
n / n\end{array}$ & Інв. № $\mathrm{H}$ - & $\begin{array}{c}\text { Книга } \\
\text { надход- } \\
\text { жень }\end{array}$ & $\begin{array}{c}\text { Назва } \\
\text { та короткий опис предмета }\end{array}$ & 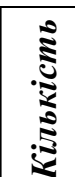 \\
\hline 70. & $\mathrm{H}-42$ & KB-2807 & $\begin{array}{l}\text { Монета альбертусталер, Нідерланди, Альберт і Єлизавета, } \\
1616 \text { р.-1 шт., } 162 . ? \text { р.-1 шт. }\end{array}$ & 2 \\
\hline 71. & H-46 & KB-2807 & Монета левендальдер, Голандська республіка, 1639 р. & 1 \\
\hline 72. & $\mathrm{H}-542$ & KB-2851 & Монета грош коронний, Польща, Сигізмунд III, 1624 р. & 1 \\
\hline 73. & $\begin{array}{l}\mathrm{H}-546-(1- \\
32)\end{array}$ & KB-2851 & $\begin{array}{l}\text { Монета грош, Польща, Сигізмунд III, } 16 . . ? \text { p.-1 шт., } 162 . ? \text { p.- } \\
5 \text { шт., } 1620 \text { р.-2 шт., } 1624 \text { р.-6 шт., } 1627 \text { p.-5 шт., } 1625 \text { р.-3 шт., } \\
1626 \text { р.-10 шт. }\end{array}$ & 32 \\
\hline 74. & H-547-(1-3) & KB-2851 & $\begin{array}{l}\text { Монета 6-грошовик коронний, Польща, Сигізмунд III, } \\
1620,1624,1625 \text { рр. }\end{array}$ & 3 \\
\hline 75. & H-548-(1-8) & KB-2851 & $\begin{array}{l}\text { Монета 3-грошовик коронний, Польща, Сигізмунд III, } \\
1621 \text { р.-2 шт., } 1622 \text { р.-2 шт., } 1623 \text { р.-2 шт., } 1624 \text { р.-2 шт. }\end{array}$ & 8 \\
\hline 76. & H-549 & KB-2851 & Монета орт коронний, Польща, Сигізмунд III, 1623 р. & 1 \\
\hline 77. & H-550-(1-5) & KB-2851 & $\begin{array}{l}\text { Монета півторак, Швеція, Христина, } 1647 \text { р.-1 шт., } 1649 \text { р.- } \\
1 \text { шт., } 1634 \text { р.-1 шт., } 1635 \text { р.-2 шт. }\end{array}$ & 5 \\
\hline 78. & $\mathrm{H}-551-(1-4)$ & KB-2851 & Монета грош, Швеція, Густав Адольф, 1629 р.-2, 1630 р.-2 шт. & 4 \\
\hline 79. & $\begin{array}{l}\mathrm{H}-552-(1- \\
25)\end{array}$ & KB-2851 & $\begin{array}{l}\text { Монета півторак, Швеція, Густав Адольф, } 16 . . ? \text { р.-1 шт., } \\
1622 \text { р.-1 шт., } 163 . ? \text { р.-2 шт., } 1632 \text { р.-2 шт., } 1632 \text { р.-4 шт., } \\
1633 \text { р.-4 шт., } 1633 \text { р.-12 шт., } 1635 \text { р.-1 шт. }\end{array}$ & 25 \\
\hline 80. & H-553-(1-9) & KB-2851 & $\begin{array}{l}\text { Монета півторак, Швеція, Густав Адольф, 163.?p.-1 шт., } \\
1629 \text { р.-1 шт., } 1630 \text { р.-5 шт., } 1631 \text { р.-2 шт. }\end{array}$ & 9 \\
\hline 81. & H-554-(1-7) & KB-2851 & $\begin{array}{l}\text { Монета півторак, Швеція, Густав Адольф, } 1622 \text { р.-1 шт., } \\
1623 \text { р.-3 шт., } 1624 \text { р.-3 шт. }\end{array}$ & 7 \\
\hline 82. & H-555-(1-7) & KB-2851 & $\begin{array}{l}\text { Монета півторак, Прусія, Георг Вільгельм, } 1622 \text { р.-3 шт., } \\
1623 \text { р.-2 шт., } 1624 \text { р.-2 шт. }\end{array}$ & 7 \\
\hline 83. & $\begin{array}{l}\mathrm{H}-556-(1- \\
17)\end{array}$ & KB-2851 & $\begin{array}{l}\text { Монета півторак, Прусія, Георг Вільгельм, } 162 . ?-1 \text { шт., } 1624 \text { р.- } \\
1 \text { шт., } 1625 \text { р.-5 шт., } 1626 \text { р.-8 шт., } 1627 \text { р.-2 шт. }\end{array}$ & 17 \\
\hline 84. & $\begin{array}{l}\mathrm{H}-543-(1- \\
\quad 60)\end{array}$ & KB-2851 & $\begin{array}{l}\text { Монета грош коронний, Річ Посполита, Сигізмунд III, } \\
1623 \text { р.-7 шт., } 1624 \text { р.-37 шт., } 1625 \text { р.-2 шт., } 1627 \text { р.-4 шт., } \\
162 . ? \text { р.-1 шт., } 16 . . ? \text { р.-9 шт. }\end{array}$ & 60 \\
\hline 85. & H-544-(291) & KB-2851 & $\begin{array}{l}\text { Монета півторак коронний, Річ Посполита, Сигізмунд III, } \\
1619 \text { р.-1 шт., } 162 . ? \text { p.-26 шт., } 1620 \text { р.-9 шт. } 1621 \text { р.-25 шт., } \\
1622 \text { p.-53 шт., } 1623 \text { р.-81 шт., } 1624 \text { p.-48 шт., } 1625 \text { р.-28 шт., } \\
1626 \text { р.-13 шт., } 1627 \text { р.-7 шт. }\end{array}$ & $\begin{array}{c}29 \\
1\end{array}$ \\
\hline 86. & $\begin{array}{l}\text { H-545-(1- } \\
93)\end{array}$ & KB-2851 & $\begin{array}{l}\text { Монета грош коронний, Річ Посполита, Сигізмунд III, } \\
20 \text {-і рр. ХУІІ ст. }\end{array}$ & 93 \\
\hline 87. & $2262(1-265)$ & KB-290 & Монета копійка, Росія, Петро I, кін. ХУІІ ст. & $\begin{array}{c}26 \\
5\end{array}$ \\
\hline 88. & 2261 & $3-290$ & Монета 1 крб, Росія, Петро I, 1719 р. & 1 \\
\hline 89. & 61 & B-290 & 1 крб, Росія, Петро I, 1720 р. & 1 \\
\hline 90. & 2261 & B-290 & Монета 1 крб, Росія, Катерина I, 1725 р. & 1 \\
\hline 91. & 2261 & B-290 & Монета 1 крб, Росія, Анна, 1732 р. & 1 \\
\hline 92. & 2261 & KB-290 & Монета 1 крб, Росія, Анна, 1734 р. & 1 \\
\hline 93. & $2261-(1-3)$ & КВ-290 & $\begin{array}{l}\text { Монета } 1 \text { крб, Росія, Анна Іоанівна, } 1731 \text { р.-1 шт., } \\
1734 \text { р.-1 шт., } 1736 \text { р.-1 шт. }\end{array}$ & 3 \\
\hline 94. & 2261 & KB-290 & Монета 1 крб-«хрестовик», Росія, Петро I, 1723 р. & 1 \\
\hline 95. & 2261 & B-290 & Монета полтина, Росія, Петро I, 1724 р. & 1 \\
\hline 96. & 2261 & KB-290 & Монета 1 крб, Росія, Катерина I, 1725 р. & 1 \\
\hline 97. & $2262(1-124)$ & KB-290 & Монета копійка, Росія, Петро I, 16 & \begin{tabular}{|c|}
12 \\
4
\end{tabular} \\
\hline 98. & 2645 & KB-306 & Монета 1 крб, Росія, Слизавета, 1752 р. & 1 \\
\hline 99. & $\mathrm{H}-142$ & KB-3116 & Дукач, Росія, 1896 р. & 1 \\
\hline 100. & $\mathrm{H}-185$ & KB-3144 & Монета 50 коп., РРФСР, 1921 р. & 1 \\
\hline
\end{tabular}




\begin{tabular}{|c|c|c|c|c|}
\hline $\begin{array}{c}\text { № } \\
n / n\end{array}$ & Інв. № $\mathrm{H}$ - & $\begin{array}{c}\text { Книга } \\
\text { надход- } \\
\text { жень }\end{array}$ & $\begin{array}{c}\text { Назва } \\
\text { та короткий опис предмета }\end{array}$ & 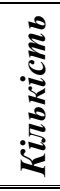 \\
\hline 101. & H-181 & KB-3191 & Монета орт коронний, Польща, Сигізмунд III, 1622 р. & 1 \\
\hline 102. & H-182 & KB-3191 & Монета тригрошовик, Польща, Сигізмунд III, 1622 р. & 1 \\
\hline 103. & $\mathrm{H}-178$ & KB-3191 & Монета 50 коп., РРФСР, 1921 р. & 1 \\
\hline 104. & $\mathrm{H}-227$ & KB-3223 & Дукач. Росія, 1 крб. 1812 р. & 1 \\
\hline 105. & $\mathrm{H}-228$ & KB-3224 & Дукач. 1 крб. 183? р. & 1 \\
\hline 106. & H-229 & KB-3235 & Дукач, Росія, XIX ст. & 1 \\
\hline 107. & $\mathrm{H}-230$ & KB-3235 & Дукач, Росія, початок XX ст. & 3 \\
\hline 108. & $\mathrm{H}-231$ & KB-3235 & Дукач, Росія, початок XX ст. & 5 \\
\hline 109. & $\mathrm{H}-238$ & KB-3250 & Монета 1 крб, Росія, Микола II, 1899 р. & 1 \\
\hline 110. & $\begin{array}{l}\mathrm{H}-247-(1- \\
10)\end{array}$ & КВ-3265 & Монета 50 коп., СРСР, 1924 р. & 10 \\
\hline 111. & H-341-1-2 & KB-3371 & Монета 1 крб, Росія, Микола II, 1897 р. & 2 \\
\hline 112. & $\mathrm{H}-342$ & KB-3371 & Монета 15 коп., Росія, Микола II, 1902 р. & 1 \\
\hline 113. & $\mathrm{H}-340$ & KB-3371 & Монета, Римська імперія & 1 \\
\hline 114. & $\mathrm{H}-349$ & KB-3375 & Дукач, Росія, початок XX ст. & 1 \\
\hline 115. & H-368-1-2 & KB-3384 & Монета 50 коп., РРФСР, 1922 р. & 2 \\
\hline 116. & $\mathrm{H}-369-(1-8)$ & KB-3384 & Монета 50 коп., СРСР, 1924 р. & 8 \\
\hline 117. & $\mathrm{H}-378$ & KB-3417 & Дукач. II пол. XIX ст. & 1 \\
\hline 118. & H-389 & KB-3468 & Монета 1 крб, РРФСР, 1921 р. & 1 \\
\hline 119. & H-390-(1-3) & KB-3468 & Монета «один полтинник», СРСР, 1924 р. & 3 \\
\hline 120. & H-391 & KB-3468 & Монета 1 крб, СРСР, 1924 р. & 1 \\
\hline 121. & $\mathrm{H}-426$ & KB-3570 & Монета 1 крб, Росія, 1898 р. & 1 \\
\hline 122. & $\mathrm{H}-427$ & KB-3570 & Монета «один полтинник», СРСР, 1924 р. & 1 \\
\hline 123. & $\mathrm{H}-452$ & KB-3666 & Дукач, Росія, кін. ХІХ ст. & 1 \\
\hline 124. & H-462-(1-7) & KB-3684 & $\begin{array}{l}\text { Монета півторак, Польща, Сигізмунд III, } \\
162 . . ? \text { р., } 1622 \text { р., } 1626 \text { р. }\end{array}$ & 7 \\
\hline 125. & $\mathrm{H}-464$ & KB-3684 & Монета півторак, Польща, Владислав, 1633 р. & 1 \\
\hline 126. & $\mathrm{H}-463-(1-2)$ & KB-3684 & Монета півторак, Прусія, Георг Вільгельм, 1626 р. & 2 \\
\hline 127. & $\mathrm{H}-466$ & KB-3690 & Дукач, поч. XX ст. & 1 \\
\hline 128. & $\mathrm{H}-467$ & KB-3690 & Дукач. 1 крб, 1842 р. & 1 \\
\hline 129. & $\mathrm{H}-468$ & KB-3690 & Дукач, поч. XX ст. & 1 \\
\hline 130. & $\mathrm{H}-469$ & KB-3700 & Дукач, поч. XX ст. & 1 \\
\hline 131. & $\mathrm{H}-470$ & KB-3706 & Дукач, поч. XX ст. & 1 \\
\hline 132. & $\mathrm{H}-471$ & KB-3710 & Дукач, поч. XX ст. & 1 \\
\hline 133. & $\mathrm{H}-472$ & KB-3718 & Дукач. 50 коп., 1899 р. & 1 \\
\hline 134. & $\mathrm{H}-473$ & KB-3727 & Дукач. 15 коп., 1865 р. & 1 \\
\hline 135. & $\mathrm{H}-474$ & KB-3728 & Дукач, кін. XIX ст. & 1 \\
\hline 136. & $\mathrm{H}-485$ & KB-3745 & Дукач «цариця» & 1 \\
\hline 137. & $\mathrm{H}-483$ & KB-3751 & Монета 1 крб, Росія, Микола II, 1896 р. & 1 \\
\hline 138. & $\mathrm{H}-484$ & KB-3751 & Монета 1 крб, Росія, Микола II, 1897 р. & 1 \\
\hline 139. & $\mathrm{H}-498-(1-7)$ & KB-3758 & Монета «один полтинник», СРСР, 1924 р. & 7 \\
\hline 140. & $\mathrm{H}-499$ & KB-3758 & Монета «один полтинник», СРСР, 1925 р. & 1 \\
\hline 141. & $\mathrm{H}-500$ & KB-3758 & Монета «один полтинник», СРСР, 1926 р. & 1 \\
\hline 142. & H-501 & KB-3758 & Монета «один полтинник», СРСР, 1927 р. & 1 \\
\hline 143. & $\mathrm{H}-486$ & KB-3766 & Дукач, 1904 р. & 1 \\
\hline 144. & H-487 & KB-3769 & Монета 1 крб, Росія, Микола II, 1896 р. & 2 \\
\hline 145. & $\mathrm{H}-488$ & KB-3769 & Монета 1 крб, Росія, Микола II, 1898 р. & 1 \\
\hline 146. & H-489 & KB-3769 & Монета 50 коп., Росія, Микола II,1896 р. & 1 \\
\hline 147. & $\mathrm{H}-502$ & KB-3774 & Монета «один полтинник», СРСР, 1924 p. & 1 \\
\hline 148. & H-503 & KB-3774 & Монета «один полтинник», СРСР, 1927p. & 1 \\
\hline 149. & $\mathrm{H}-506$ & KB-3777 & Монета 50 коп., Росія, Микола II, 1896 р. & 1 \\
\hline
\end{tabular}




\begin{tabular}{|c|c|c|c|c|}
\hline $\begin{array}{l}\text { No } \\
n / n\end{array}$ & Iнв. № $\mathrm{H}$ - & $\begin{array}{c}\text { Книга } \\
\text { надход- } \\
\text { жень }\end{array}$ & $\begin{array}{c}\text { Назва } \\
\text { та короткий опис предмета }\end{array}$ & 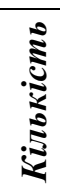 \\
\hline 150. & H-507 & KB-3777 & Монета 50 коп., Росія, Микола II, 1899 р. & 1 \\
\hline 151. & H-508 & KB-3777 & Монета 1 крб, Росія, Микола II, 1898 р. & 1 \\
\hline 152. & H-509-(1-5) & KB-3777 & Монета 50 коп., СРСР, 1924 p. & 5 \\
\hline 153. & $\mathrm{H}-510$ & KB-3777 & Монета 50 коп., РРФСР, 1922 р. & 1 \\
\hline 154. & H-511-(1-2) & KB-3777 & Монета 10 коп., СРСР, 1925 р. & 2 \\
\hline 155. & $\mathrm{H}-517$ & KB-4121 & Дукач, поч. 1877 р. & 1 \\
\hline 156. & H-518 & KB-4126 & Дукач. 1 крб, 1822 р. & 1 \\
\hline 157. & H-519 & KB-4217 & Дукач, 20-ті рр. ХХ ст. & 1 \\
\hline 158. & H-520 & KB-4227 & Дукач, 20-ті рр. ХХ ст. & 1 \\
\hline 159. & H-521 & KB-4247 & Дукач, поч. XX ст. (2 пр.) & 2 \\
\hline 160. & H-522 & KB-4248 & Дукач, Україна, XIX ст. & 1 \\
\hline 161. & H-523 & KB-4249 & Дукач, Україна, XX ст. & 1 \\
\hline 162. & H-524 & KB-4250 & Дукач, Україна, ХХ ст. (5) & 5 \\
\hline 163. & 2714 & KB-434 & Монета 1 крб, Росія, Олександр II, 1878 р. & 1 \\
\hline 164. & H-525 & KB-4376 & Дукач, XIX ст. & 1 \\
\hline 165. & H-526 & KB-4428 & Дукач, кін. XIX ст. & 1 \\
\hline 166. & H-527 & KB-4429 & Дукач, 20-ті рр. ХХ ст. & 1 \\
\hline 167. & H-528 & KB-4430 & Дукач, 20-ті рр. ХХ ст. & 1 \\
\hline 168. & H-557-(1-2) & KB-4513 & Монета альбертусталер, Нідерланди, 1598-1621 рр. & 2 \\
\hline 169. & H-558-(1-3) & КВ-4513 & $\begin{array}{l}\text { Монета брабантський талер, Нідерланди, Філіп ІУ, } \\
\text { 1621-1665 рр. }\end{array}$ & 3 \\
\hline 170. & H-559 & KB-4513 & $\begin{array}{l}\text { Монета брабантський пів талер, Нідерланди, Філіп ІУ, } \\
\text { 1621-1665 pр. }\end{array}$ & 1 \\
\hline 171. & $\mathrm{H}-560$ & KB-4513 & Монета риксталер, Нідерланди, Карл II, 1673 р. & 1 \\
\hline 172. & H-561-(1-2) & KB-4513 & $\begin{array}{l}\text { Монета півпатагон, Нідерланди, Альберт і Слизавета, } \\
\text { 1598-1621 pp. }\end{array}$ & 2 \\
\hline 173. & $\mathrm{H}-562$ & KB-4513 & Монета левендальдер, Нідерланди, Філіп ІУ, 1641 р. & 1 \\
\hline 174. & $\mathrm{H}-563$ & KB-4513 & Монета орт коронний, Польща, Сигізмунд III, 16.? р. & 1 \\
\hline 175. & H-564 & KB-4513 & Монета талер, Австрія-архиєпіскопство Зальцбург, 1677 р. & 1 \\
\hline 176. & $\mathrm{H}-565$ & KB-4513 & Монета півторак-«чех», Польща-Литва, Ян Казимир, 1662 р. & 1 \\
\hline 177. & $\mathrm{H}-567-(1-2)$ & KB-4513 & Монета полтина, Росія, Петро I, 1705 р. & 2 \\
\hline 178. & $\mathrm{H}-568-(1-2)$ & KB-4513 & Монета гривна, Росія, Петро I, 1705 р. & 2 \\
\hline 179. & H-569-(1-2) & KB-4513 & Монета алтин, Росія, Петро I, 1704 р. & 2 \\
\hline 180. & $\begin{array}{l}\mathrm{H}-566-(1- \\
9545)\end{array}$ & КВ-4513 & Монета копійка, Росія, Петро I, кін. ХУІІ ст. & $\begin{array}{l}95 \\
45 \\
\end{array}$ \\
\hline 181. & $\mathrm{H}-588-(1,2)$ & KB-4754 & Монета «один полтинник», СРСР, 1924 р. & 2 \\
\hline 182. & 2776 & KB-481 & Монета талер, Швейцарія - м. Сан-Галлен, 1622 р. & 1 \\
\hline 183. & 2776 & KB-481 & $\begin{array}{l}\text { Монета альбертусталер, Нідерланди, Альберт і Слизавета, } \\
\text { 1599-1612 рр. }\end{array}$ & 1 \\
\hline 184. & $2776-(1-2)$ & КВ-481 & $\begin{array}{l}\text { Монета талер брабантський, Нідерланди, Філіп ІУ, } \\
1630 \text { р., } 1636 \text { р. }\end{array}$ & 2 \\
\hline 185. & 2776 & KB-481 & Монета талер, Швейцарія - м. Сан-Галлен, 162..? р. & 1 \\
\hline 186. & 2776 & КВ-481 & Монета талер, Німеччина, Фердинанд, 1564-1565 рр. & 1 \\
\hline 187. & 2776 & KB-481 & Монета риксдаальдер, Голландська республіка, 1621 р. & 1 \\
\hline 188. & 2776 & KB-481 & Монета риксдаальдер, Нідерланди, 1620 р. & 1 \\
\hline 189. & 2776 & КВ-481 & $\begin{array}{l}\text { Монета риксдаальдер, Голландська республіка - м. Кампен, } \\
1620 \text { р. }\end{array}$ & 1 \\
\hline 190. & 2776-(1-6) & KB-481 & $\begin{array}{l}\text { Монета левендаальдер, Голландська республіка, } 1636 \text { р.-1 шт., } \\
1642 \text { р.-3 шт., } 1644 \text { р.-1 шт., } 1648 \text { р.-1 шт. }\end{array}$ & 6 \\
\hline 191. & 2776 & KB-481 & $\begin{array}{l}\text { Монета левендаальдер, Голландська республіка - м. Кампен, } \\
1648 \text { р. }\end{array}$ & 1 \\
\hline 192. & $2776-(1-2)$ & КВ-481 & Монета левендаальдер, Голландська республіка, 1646 р. & 2 \\
\hline
\end{tabular}




\begin{tabular}{|c|c|c|c|c|}
\hline $\begin{array}{l}\text { № } \\
n / n\end{array}$ & Iнв. № $\mathrm{H}$ - & $\begin{array}{l}\text { Книга } \\
\text { надход- } \\
\text { жень }\end{array}$ & $\begin{array}{c}\text { Назва } \\
\text { та короткий опис предмета }\end{array}$ & 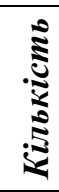 \\
\hline 193. & $2776-(1-7)$ & КВ-481 & $\begin{array}{l}\text { Монета левендаальдер, Голландська республіка, } 1641 \text { р.-3 шт., } \\
1643 \text { р.-1 шт., } 1644 \text { р.-1 шт., } 1646 \text { р.-2 шт. }\end{array}$ & 7 \\
\hline 194. & H-597 & KB-4822 & Монета 1 крб, Росія, Микола II, 1896 р. & 1 \\
\hline 195. & H-598 & KB-4823 & Монета 5 марок, Німеччина, Вільгельм, 1876 р. & 1 \\
\hline 196. & H-599 & KB-4824 & Монета 1 крб, Росія, Олександр II, 1877 р. & 1 \\
\hline 197. & $\mathrm{H}-600$ & KB-4825 & Монета 1 крб, РРФСР, 1921 р. & 1 \\
\hline 198. & H-601 & KB-4826 & Монета 5 злотих, Росія-Польща, 1838 р. & 1 \\
\hline 199. & H-602 & KB-4827 & Монета 1 крб коронаційний, Росія, Олександр III, 1883 p. & 1 \\
\hline 200. & H-603 & KB-4828 & Монета 50 коп., Росія, Микола II, 1899 р. & 1 \\
\hline 201. & H-604-(1-2) & KB-4829 & Монета 50 коп., Росія, Микола II,1896 p. & 2 \\
\hline 202. & H-616 & KB-5007 & Монета 10 коп., Росія, Микола I, 1842 p. & 1 \\
\hline 203. & H-608-1 & KB-5008 & $\begin{array}{l}\text { Монета півторак коронний, Річ Посполита, Сигізмунд III, } \\
1623 \text { р. }\end{array}$ & 1 \\
\hline 204. & H-613 & KB-5012 & $\begin{array}{l}\text { Монета грош коронний, Річ Посполита, Сигізмунд III, } \\
1587-1632 \text { pp. }\end{array}$ & 1 \\
\hline 205. & H-619-(1-4) & KB-5053 & Монета 1 крб, Росія, Микола II, 1897 р. & 4 \\
\hline 206. & H-619 & KB-5053 & Монета 1 крб, Росія, Микола II, 1899 р. & 1 \\
\hline 207. & H-620-(1-4) & KB-5054 & Монета 50 коп., Росія, Микола II, 1897 р. & 4 \\
\hline 208. & T-3911 & KB-5073 & $\begin{array}{l}\text { Пониз дукачів з намистом (8 дукачів: } 1 \text { крб, } 1890 ? \text { р.-1 шт., } \\
3 \text { шт.-1896 р., } 2 \text { шт.-1897 р., } 1 \text { шт.-1899 р.), XIX ст. }\end{array}$ & 8 \\
\hline 209. & T-3930 & КВ-5093 & $\begin{array}{l}\text { Пониз дукачів з намистом ( } 11 \text { срібних дукачів: } 50 \text { коп.-5 шт., } \\
1 \text { крб.-6 шт., } 1 \text { монета-5 злотих), ХІХ ст. }\end{array}$ & 11 \\
\hline 210. & H-622 & KB-5100 & Монета трояк коронний, Річ Посполита, Сигізмунд III, 1624 р. & 1 \\
\hline 211. & H-623 & КB-5101 & $\begin{array}{l}\text { Монета 6-грошовик коронний, Річ Посполита, Сигізмунд III, } \\
1625 \text { р. }\end{array}$ & 1 \\
\hline 212. & $\begin{array}{l}\mathrm{H}-624-(1- \\
13)\end{array}$ & KB-5102 & $\begin{array}{l}\text { Монета півторак коронний, Річ Посполита, Сигізмунд III, } \\
\text { 16..? p.-2 шт., } 162 . ? \text { p.-3 шт., } 1622 \text { р.-1 шт., } 1623 \text { р.-1 шт., } \\
1624 \text { p.-2 шт., 1625p.-3 шт., 1632p.-1 шт. }\end{array}$ & 13 \\
\hline 213. & H-625 & KB-5115 & Монета 1 крб, Росія, Микола II, 1897 р. & 1 \\
\hline 214. & H-626 & KB-5116 & Монета полтинник, СРСР, 1924 р. & 1 \\
\hline 215. & H-627 & KB-5117 & Дукач, XIX ст. (2 пр.) & 2 \\
\hline 216. & H-628 & KB-5118 & Дукач, XIX ст. (2 пр.) & 2 \\
\hline 217. & H-629 & KB-5119 & Дукач, XIX ст. (2 пр.) & 2 \\
\hline 218. & H-646-(1-2) & KB-5282 & Монета полтинник, СРСР, 1924 p. & 2 \\
\hline 219. & H-647 & KB-5283 & Монета 50 коп., Росія, Микола II, 1897 р. & 1 \\
\hline 220. & H-658 & KB-5581 & Дукач, XIX ст. & 1 \\
\hline 221. & H-706 & KB-6056 & Дукач, 1899 р. & 1 \\
\hline 222. & $\begin{array}{l}\mathrm{H}-794-(1- \\
17)\end{array}$ & KB-6063 & $\begin{array}{l}\text { Монета } 15 \text { коп., Росія, Микола II, 1870, 1899, 1900, 1901, 1902, } \\
1903 \text { рp., } 1905 \text { р.-2 шт., } 1906 \text { р.-2 шт., 1908-2 шт., 1909-2 шт., } \\
\text { 1912, 1914, } 1915 \text { рр. }\end{array}$ & 17 \\
\hline 223. & $\begin{array}{l}\mathrm{H}-795-(1- \\
39)\end{array}$ & KB-6063 & $\begin{array}{l}\text { Монета } 20 \text { коп., Росія, Олександр II, Олександр III, Микола II; } \\
\text { 1863-2, 1869-2, 1870-1. 1876-1. 1880-1, 1882-1, 1901-3, 1902-2, } \\
\text { 1903-3, 1904-1, 1905-2, 1906-3, 1907-5, 1909-3, 1910-1, 1912-1, } \\
\text { 1913-1, 1914-3, 1915-3 }\end{array}$ & 39 \\
\hline 224. & $\begin{array}{l}\text { H-796-(1- } \\
21)\end{array}$ & KB-6063 & Монета 15 коп., РРФСР, 1922 р.-3 шт., 1923 р.-18 шт. & 21 \\
\hline 225. & $\begin{array}{l}\mathrm{H}-797-(1- \\
27)\end{array}$ & KB-6063 & $\begin{array}{l}\text { Монета } 20 \text { коп., РРФСР, } 1921 \text { р.-2 шт., } 1922 \text { р.-3 шт., } \\
1923 \text { р.-22 шт. }\end{array}$ & 27 \\
\hline 226. & H-798 & KB-6063 & Монета 10 коп., РСФСР, 1923 р. & 1 \\
\hline 227. & H-798-(1,2) & KB-6063 & Монета 10 коп., СРСР, 1925 p. & 2 \\
\hline 228. & $\begin{array}{l}\text { H-799-(1- } \\
23)\end{array}$ & КВ-6063 & $\begin{array}{l}\text { Монета } 15 \text { коп., СРСР, } 1924 \text { р.-5 шт., } 1925 \text { р.-11 шт., } 1927 \text { р.- } \\
1 \text { шт., } 1928 \text { р.-3 шт., } 1929 \text { р.-1 шт., } 1930 \text { р.-2 шт. }\end{array}$ & 23 \\
\hline
\end{tabular}




\begin{tabular}{|c|c|c|c|c|}
\hline $\begin{array}{l}\text { Noo } \\
n / n\end{array}$ & Інв. № $\mathrm{H}$ - & $\begin{array}{c}\text { Книга } \\
\text { надход- } \\
\text { жень }\end{array}$ & $\begin{array}{c}\text { Назва } \\
\text { та короткий опис предмета }\end{array}$ & 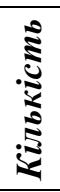 \\
\hline 229. & $\begin{array}{l}\text { H-800-(1- } \\
55)\end{array}$ & KB-6063 & $\begin{array}{l}\text { Монета } 20 \text { коп., СРСР, } 1924 \text { р.-18 шт., } 1925 \text { р.-31 шт., } \\
1928 \text { р.-1 шт., } 1927 \text { р.-3 шт., } 1929 \text { р.-1 шт., } 1930 \text { р.-1 шт. }\end{array}$ & 55 \\
\hline 230. & H-801-(1-2) & КВ-6064 & $\begin{array}{l}\text { Монета 6-грошовик коронний, Річ Посполита, Сигізмунд III, } \\
1624 \text { р. }\end{array}$ & 2 \\
\hline 231. & $\mathrm{H}-802-(1-5)$ & КВ-6064 & $\begin{array}{l}\text { Монета 3-грошовик коронний, Річ Посполита, Сигізмунд III, } \\
1621 \text { р.-2 шт., } 1622 \text { р.-1 шт., } 1623 \text { р.-1 шт., } 1624 \text { р.-1 шт. }\end{array}$ & 5 \\
\hline 232. & H-803-(1-4) & КВ-6064 & $\begin{array}{l}\text { Монета грош гданський, Річ Посполита, Сигізмунд III, } \\
1624 \text { р.-1 шт., } 1626 \text { р.-2 шт., } 1627 \text { р.-1 шт. }\end{array}$ & 4 \\
\hline 233. & $\begin{array}{l}\mathrm{H}-804-(1- \\
11)\end{array}$ & КВ-6064 & $\begin{array}{l}\text { Монета грош литовський, Річ Посполита, Сигізмунд III, } \\
\text { 1625-1627 рр. }\end{array}$ & 11 \\
\hline 234. & $\mathrm{H}-804$ & $3-6064$ & Монета грош литовський, Річ Посполита, Ян Казимир, 1652 р. & 1 \\
\hline 235. & $\begin{array}{l}\mathrm{H}-805-(1- \\
12)\end{array}$ & KB-6064 & Монета грош польський, Річ Посполита, Сигізмунд III, 1624 р. & 12 \\
\hline 236. & H-806 & -6064 & ф Ваза, 1629 р. & 1 \\
\hline 237. & $\begin{array}{l}\mathrm{H}-817-(1- \\
78)\end{array}$ & КВ-6064 & $\begin{array}{l}\text { Монета півторак коронний, Річ Посполита, Сигізмунд III, } \\
162.2 \text { p.-5 шт., } 1617 \text { р.-1 шт., } 1620 \text { p.-2 шт., } 1621 \text { р. шт.-7, } \\
1622 \text { р.-12 шт., } 1623 \text { р.-19 шт., } 1624 \text { р.-17 шт., } 1625 \text { р.-10 шт., } \\
1626 \text { р.-1 шт., } 1627 \text { р.-4 шт. }\end{array}$ & 78 \\
\hline 238. & H-817 & KB-6064 & $\begin{array}{l}\text { Монета півторак ризький, Річ Посполита, Сигізмунд III, } 1620 \\
\text { p. }\end{array}$ & 1 \\
\hline 239. & H-817-(1-2) & KB-6064 & $\begin{array}{l}\text { Монета півторак, Прусія, Георг Вільгельм, } 1626 \text { р.-1 шт., } \\
1627 \text { р.-1 шт. }\end{array}$ & 2 \\
\hline 240. & $\begin{array}{c}\mathrm{H}-819-(1- \\
12)\end{array}$ & KB-6064 & $\begin{array}{l}\text { Монета півторак, Швеція, Густав II Адольф, } 1624 \text { р.-1 шт., } \\
163 . ? \text { р.-2 шт., } 1630 \text { р.-2 шт., } 1632 \text { р.-3 шт., } 1633 \text { р.-4 шт. }\end{array}$ & 12 \\
\hline 241. & H-820-(1-9) & KB-6064 & $\begin{array}{l}\text { Монета півторак, Прусія, Георг Вільгельм, } 1622 \text { р.-4 шт., } \\
1623 \text { р.-1 шт., } 1624 \text { р.-3 шт., } 1625 \text { р.-1 шт. }\end{array}$ & 9 \\
\hline 242. & H-822 & KB-6064 & Монета драйпьолькер, Швеція, Христина Августа Ваза, 1648 р. & 1 \\
\hline 243. & H-821-(1-4) & KB-6064 & $\begin{array}{l}\text { Монета півторак, Прусія, Георг Вільгельм, } 1625 \text { р.-2 шт., } \\
1626 \text { р.-2 шт. }\end{array}$ & 4 \\
\hline 244. & 2939 & -623 & 1 крб, Росія, Олександр I, 1812 р. & 1 \\
\hline 245. & H-708 & $3-6298$ & CPCP, 1926 p. & 1 \\
\hline 246. & H-709 & KB-6299 & Монета 5 марок, Німецький Рейх, 1936 р. & 1 \\
\hline 247. & H-713-(1-2) & КВ-6417 & $\begin{array}{l}\text { Монета півторак коронний, Річ Посполита, Сигізмунд III, } \\
1621,1622 \text { рр. }\end{array}$ & 2 \\
\hline 248. & 898 & KB-7050 & Дукач, 1896 р. & 1 \\
\hline 249. & $3100-(1-2)$ & KB-775 & Монета півторак коронний, Польща, Сигізмунд III, 1621 p. & 2 \\
\hline 250. & $3100-(1-2)$ & КВ-775 & $\begin{array}{l}\text { Монета півторак коронний, Швеція, Густав II Адольф, } \\
1623 \text { р.-1 шт., } 1630 \text { р.-1 шт. }\end{array}$ & 2 \\
\hline
\end{tabular}

\section{REFERENCES}

Bakalets, O. A. (2004). Taler v hroshovomu obihu Ukrainy kintsia XVI-pershoi chverti XVIII st. Bar, 2004. pp. 11. [in Ukrainian].

Boiko-Haharin, A. S. \& Kuzmenko, A. V. (2016) Falshyvi monety chasiv Syhizmunda III Vaza u kolektsii NIEZ «Pereiaslav». [The counterfeit coins of Sigismund III Vasa in the collection of the NHER «Pereyaslav»]. Pereiaslavskyi litopys. 9. 186-188. [in Ukrainian].

Boiko-Haharin, A. S. (2018) Hazetna periodyka yak dzherelo vyvchennia protsesiv falshuvannia monet ta banknot v kintsi XIX-pochatku XX stolittia. [The newspapers periodicals as the source of study of the process of counterfeiting coins and banknotes during the late XIX the early XX centuries]. Ukrainskyi numizmatychnyi shchorichnyk. 2. 132-149. [in Ukrainian]. 
Boiko-Haharin, A. \& Korpusova, I. (2017) Monetno-vahovi zlyvky hryvni ta yikh tohochasni pidrobky z kolektsii Odeskoho arkheolohichnoho muzeiu. [Coin-weight hryvnia ingots and their counterfeits from the collection of the Odessa Archaeological Museum]. Zapysky otdela numyzmatyky y torevtyky Odesskoho arkheolohycheskoho muzeia. 3. 120-132. [in Ukrainian].

Bojko-Gagarin, A. S. (2015) Fal'shivyj vengerskij taler 1580 goda. [Fake Hungarian Thaler of 1580]. Numizmatika i Faleristika. (1). 8. [in Russian].

Bojko-Gagarin, A. S. (2017) Fal'shivomonetnichestvo v Central'noj i Vostochnoj Evrope $v$ jepohu Srednevekov'ja i rannego Novogo vremeni [The coin counterfeiting in Central and Eastern Europe in the Middle age and early Modern time]. Kiev: Ukrainskaja konfederacija zhurnalistov. [in Russian].

Demuz, I. O. (2011) Muzei pry zakladakh osvity Pereiaslavshchyny [Museum at educational institutions at Pereyaslav region]. Pereiaslavskyi litopys. 2. 22-37. [in Ukrainian].

Dunaina, I. H. (2009) Dukachi ta lymany z kolektsii NHER «Pereiaslav» [Dukaches and estuaries from the NHER «Pereiaslav» Collection]. «Pereiaslav». Pereiaslavika: Naukovi zapysky NHER «Pereiaslav». 3(5). 115-118. [in Ukrainian].

Kalakura, Ya. S. \& Voitsekhivska, I. N. (2002) Istorychne dzhereloznavstvo. Pidruchnyk dlia studentiv istorychnykh spetsialnostei vyshchykh navchalnykh zakladiv. [Historical source studies. Textbook for students of historical specialties of higher educational institutions]. Kyiv: Lybid. [in Ukrainian].

Kocur, V. P. (2016) Talery i efimok s priznakami v kollekcii Nacional'nogo istorikokul'turnogo zapovednika "Perejaslav», kak istochnik denezhnogo obrashhenija v Ukraine v XVI-XVIII vekah. [Thalers and "Yefimoks with signs" in the collection of the National Historical and Cultural Reservation "Pereyaslav" as a source of the study of money circulation in Ukraine in the XVI-XVIII centuries]. Acta Archaeologia Lodziensia. (61). 77-80. [in Russian].

Kolybenko, O., \& Kolybenko, O. (2016) Znakhidky olviiskykh monet na Pereiaslavshchyni. Abstract of papers: «Aktualni problemy numizmatyky $v$ systemi dopomizhnykh istorychnykh dystsyplin». 22-23 chervnia 2016 r. Kirovohrad-Kyiv-PereiaslavKhmelnytskyi, 2016. pp. 18-21. [in Ukrainian].

Kotliar, M. F. (1971). Hroshovyi obih na terytorii Ukrainy doby Feodalizmu. Kyev, 1971. [in Ukrainian].

Kotsur, V. P. \& Boiko-Gagarin, A. S. (2019) Napoleon russian forged assignations in Naddniprianshchyna (over Dnipro land). East European historical bulletin. (11). 66-77. [in English].

Kotsur, V. P. (2013). Aktualni napriamy ta orhanizatsiini zasady suchasnykh doslidzhen serednovichnoi numizmatyky v Ukraini. [Current trends and organizational principles of modern studies of medieval numismatics in Ukraine]. Naukovi zapysky z ukrainskoi istorii [The scientifical notes of the Ukrainian history]. (33), 3-8. [in Ukrainian].

Kotsur, V. P. (2015) Yefimok z pryznakom u kolektsii Natsionalnoho istorykoetnohrafichnoho zapovidnyka «Pereiaslav». [Efimok with a sign in the collection of National Historical and Ethnographic Reservation «Pereyaslav»]. Abstract of papers: «Aktualni problemy numizmatyky u systemi spetsialnykh haluzei istorychnoi nauky», pp. 59-60. [in Ukrainian].

Kotsur, V. P. (2017) Istoriohrafiia ukrainskoho skarboznavstva [The historiography of the Ukrainian treasurology]. Ukrainskyi Numizmatychnyi Shchorichnyk. 1. 15-33. [in Ukrainian].

Kotsur, V. P. (2018) Portuhal Bohemii z kolektsii Natsionalnoho Kyievo-Pecherskoho istoryko-kulturnoho zapovidnyka [The portugal of Bohemia in the collection of the National Kyiv-Pechersk historical and cultural reservation]. Abstracts of papers: Aktualni pytannia 
numizmatyky $v$ systemi spetsialnykh haluzei istorychnoi nauky. (pp. 89-90). Medzhybizh Pereiaslav-Khmelnytskyi-Kropyvnytskyi-Kyiv. [in Ukrainian].

Kotsur,V. (2016) Methodological issues of modern numismatic research: materials of black archeology and scientific research. Abstract of papers: Studia I Materialy Forum Numizmatyczne, Pieniadz I Mennice, (1), (pp. 5-9). [in English].

Mielczarek, M., \& Orlyk, V. (2019). New find of Olbian coins. Tarashcha district, Kyiv region, Ukraine. Skhidnoievropeiskyi Istorychnyi Visnyk [East European Historical Bulletin], 13, 33-39. doi: 10.24919/2519-058x.13.190763

Nesterenko, V. I. (2012) Osoblyvosti zolotarskoho remesla Livoberezhzhia Cherkashchyny (za fondovoiu kolektsiieiu dukachiv). [Features of the Gold Craft of the Left Bank of Cherkasy region (according to the stock collection of Dukachs)]. Pereiaslavika: Naukovi zapysky NHER «Pereiaslav». 6 (8). 187-197. [in Ukrainian].

Orlyk V. (2010). Fiskal'nyy aparat Het'manshchyny (1654-1764 rr.) [Fiscal apparatus of the Hetmanate (1654-1764 years)]. Borysten, 8, 25-28. [in Ukrainian].

Orlyk, S. V., Boiko-Haharin, A. S. (2017) Falshyvomonetnytstvo v Ukraini v roky Pershoi svitovoi viiny [Money counterfeiting in Ukraine during the WWI]. Ukrainskyi numizmatychnyi shchorichnyk [The Ukrainian Numismatic Annual], (1), 143-164. [in Ukrainian].

Orlyk, V. \& Boiko-Haharin, A. (2020) Monety, peredani z Vseukrainskoho Istorychnoho Muzeiu imeni Tarasa Shevchenka do Derzhavnoho Banku SRSR v 1933-1934 rr. [Coins transferred from the All-Ukrainian History Museum named after Taras Shevchenko to the State Bank of the USSR in 1933-1934.]. Abstract of papers. "Utracone kolekcje numizmatyczne». 6-7 grudnia 2018 r. Warszawa: Zamek Krolewski w Warszawie. pp. 225-237. [in Ukrainian].

Orlyk, V. (2006). Yehor Kankrin i fiskalna polityka Rosiiskoi imperii v Pravoberezhnii Ukraini v druhii chverti XIX st. [Yegor Kankrin and the fiscal policy of the Russian Empire in Right-Bank Ukraine in the second quarter of the nineteenth century]. Spetsialni istorychni dystsypliny:pytannia teorii ta metodyky [Special Historical Disciplines: Theory and Methodology]. 13. Nats. akad. nauk Ukrainy, In-t istorii Ukrainy. 97-110. [in Ukrainian].

Orlyk, V. (2016) A Coin Hoard of Pre-Reform Shillings of the Grand Master Michael Küchmeister von Sternberg Found in Chernihivschyna. Acta Archaeologica Lodziensia, 62, 9397. [in English].

Orlyk, V. (2018). Skarb ol'viys'kykh «borysfeniv» iz s. Yaselka Ochakivs'koho rayonu Mykolayivs'koyi oblasti. Aktual'ni problemy numizmatyky u systemi spetsial'nykh haluzey istorychnoyi nauky: tezy dopovidey V-yi mizhnarodnoyi naukovo-praktychnoyi konferentsiyi, 21-22 chervnya 2018 r. Medzhybizh - Pereyaslav-Khmel'nyts'kyy - Kropyvnyts'kyy - Kyiv, S.13-14. [in Ukrainian].

Orlyk, V. M. (2004) Problemy istorii podatkovoi polityky Rosiiskoi imperii v ukrainskomu seli kintsia XVIII - pochatku XX st. v "ahrarnii" istoriohrafii. [The problems of the history of the tax policy of the Russian empire in the Ukrainian suburb in the end of the XVIII - the beginning of the XX cent in the "agricultural" historiography]. Istoriia Ukrainy. Malovidomi imena, podii, fakty. [The history of Ukraine. Unknown names, events and facts]. (27). 224-239. [in Ukrainian].

Orlyk, V. M. (2007). Podatkova polityka Rosiiskoi imperii v Ukraini v doreformenyi period: monohrafiia [Tax policy of the Russian Empire in Ukraine in pre-reform period: a monograph]. Kirovohrad: Imeks-LTD. [in Ukrainian].

Orlyk, V. M. (2007). Selyanstvo Ukrayiny v fiskal'niy politytsi imperiy Romanovykh $i$ Habsburhiv [The peasantry of Ukraine in the fiscal policy of the Romanov and Habsburg empires]. Problemy istoriyi Ukrayiny XIX-pochatku XX st. - Problems of the History of Ukraine of XIX - beginning XX cc., 13, 83-86 [in Ukrainian]. 
Orlyk, V. M. (2009). Kozatstvo Livoberezhnoyi Ukrayiny u finansoviy politytsi Rosiys'koyi imperiyi u kintsi XVIII - seredyni XIX st. [Cossacks of the Left Bank Ukraine in the financial policy of the Russian Empire at the end of the 18th - the middle of the XIX century]. Problemy istoriyi Ukrayiny XIX-pochatku XX st., XVI 83-97. [in Ukrainian].

Orlyk, V. M. (2011) Rehionalni osoblyvosti podatkovoi polityky uriadu Rosiiskoi imperii $v$ doreformenyi period: problemy metodolohii doslidzhennia. [Regional features of the tax policy of the Government of the Russian Empire in the pre-reform period: problems of research methodology]. Hurzhiivski istorychni chytannia. 4. 281-283. [in Ukrainian].

Orlyk, V. M. (2011). Derzhavni finansy Rosiiskoi imperii pershoi polovyny XIX st.: stan ta osnovni tendentsii. [The state finances of the Russian Empire in the first half of the XIX century: the condition and main tendencies]. Naukovyi visnyk Izmailskoho derzhavnoho humanitarnoho universytetu, (30), 96-108. [in Ukrainian].

Orlyk, V., Kotsur, V. \& Tsyganenko, L. (2019). Klad ol'viyskikh monet «borisfenov», naydennyy v Gorodishchenskom rayone Cherkasskoy oblasti vesnoy 2018 goda. Acta Archaeologica Lodziensia, 65, 37-48. [in Russian].

Orlyk, W. (2014) Falszywy dukat lenny z 1588 roku odkryty na Ukrainie [The false ducat of 1588 excavated in Ukraine]. Przeglad Numizmatyczny. 3 (86). 48. [in Polish].

Priadko, O. \& Yurchenko, O. (2015) Numizmatychni znakhidky rannomodernoho chasu $z$ c. Prystromy na Pereiaslavshchyni. [Numismatic findings of early modern time from Prystromy in Pereyaslav Region]. Novi doslidzhennia pamiatok Kozatsbkoi doby v Ukrainy. 24. 143-148. [in Ukrainian].

Priadko, O. \& Yurchenko, O. (2017) Novi znakhidky rymskykh monet na Pereiaslavshchyni. [New finds of Roman coins in Pereyaslav Region]. Nizhynska Starovyna. Seriia Pamiatkoznavstvo Pivnichno-Skhidnoho rehionu Ukrainy. 9. 24 (27). 84-91. [in Ukrainian].

Priadko, O. (2019) Znakhidka monety Volodymyra Olherdovycha XIV st. z m. Pereiaslav. [Find of the coin of Vladimir Olgerdovich of XIV century from Pereyaslav]. Novi doslidzhennia pamiatok Kozatskoi doby v Ukrainy. 28. 125-126. [in Ukrainian].

Spasskij, I. G. (1971) Katalog efimkov 1655 g. [Catalog of Efimoks 1655]. Numizmatika i Sfragistika. (4). 102-103. [in Russian].

Teteria, D. \& Priadko, O. (2016) Znakhidka vizantiiskoi monety na terytorii PivdennoZakhidnoi Pereiaslavshchyny. [Finding of Byzantine coin in the territory of Southwestern Pereyaslav Region]. Abstract of papers: «Aktualni problemy numizmatyky u systemi spetsialnykh haluzei istorychnoi nauky», pp. 26-29. [in Ukrainian].

Yurchenko, O. (2013) Dukach iz s. Letsky na Pereiaslavshchyni. [Dukach from Lecki in Pereyaslav Region]. Naukovi zapysky z ukrainskoi istorii. 33. 168-169. [in Ukrainian].

Zuber, S. \& Zakharchenko, C. (2011) Muzei ukrainskykh obriadiv NHER «Pereiaslav»: do istorii zapochatkuvannia ta provedennia narodnykh sviat. [NHER «Pereiaslav» Museum of Ukrainian Rites: Towards a History of the Beginning and Conduct of National Holidays]. Abstract of papers: Zhovkivski chytannia 2011. Muzei v suchasnomu sviti. Lyviv: pp. 88-91. [in Ukrainian]. 


\section{Ілюстрації}

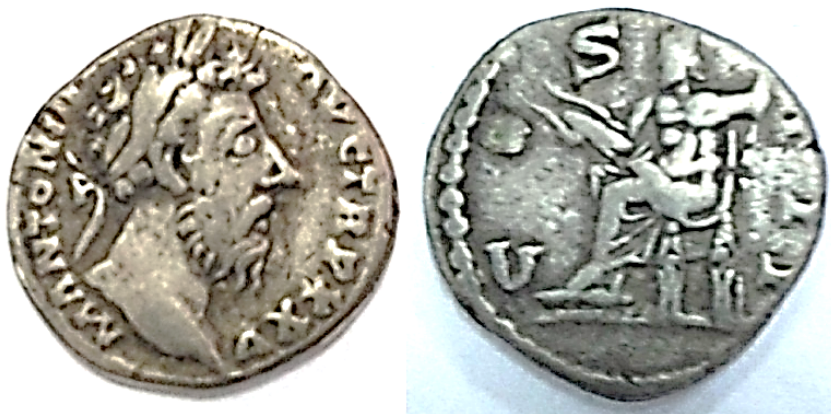

Рис. 1.

Римська імперія, Марк Аврелій (161-180), денарій 170-171 рр., м.д. Рим (RIC III 228). Інв. № H-340.

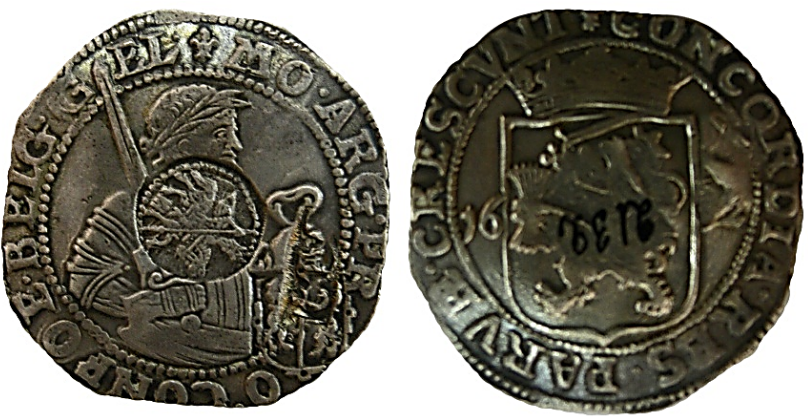

Рис. 3.

Московський «Єфімок з ознаками» на левендаальдері м. Гельдерна 16(?)2 р.; з колекції HIE3 «Переяслав». Інв. № Н-2132.
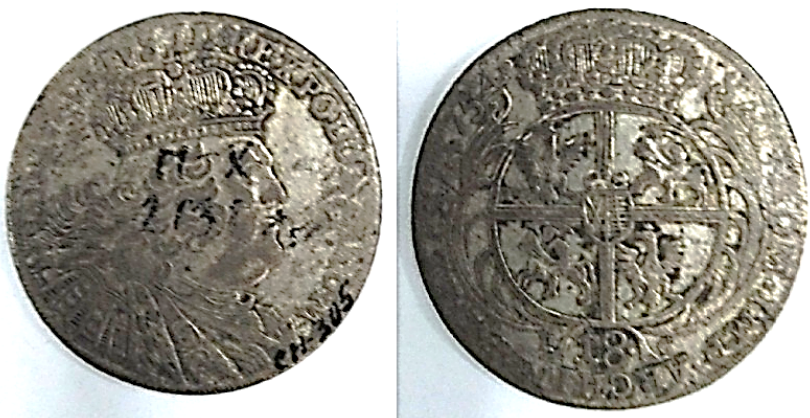

Pис. 2.

Річ Посполита, Август III Сильний, орт 1754 року. Інв. № H-2131.
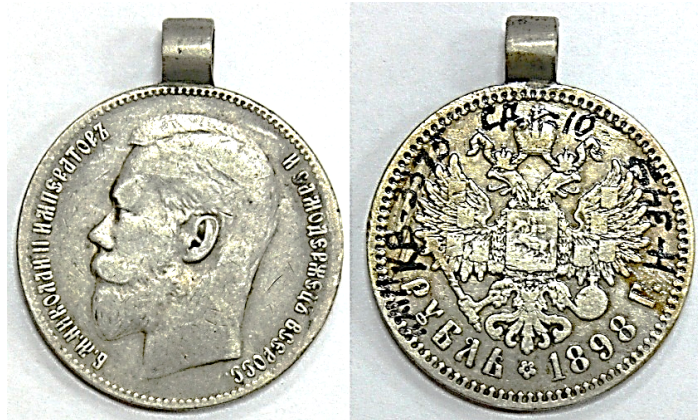

Рис. 5.

Російська імперія, Микола II Романов, рубль 1898 рік $з$ припаяним вушком («дукач»)

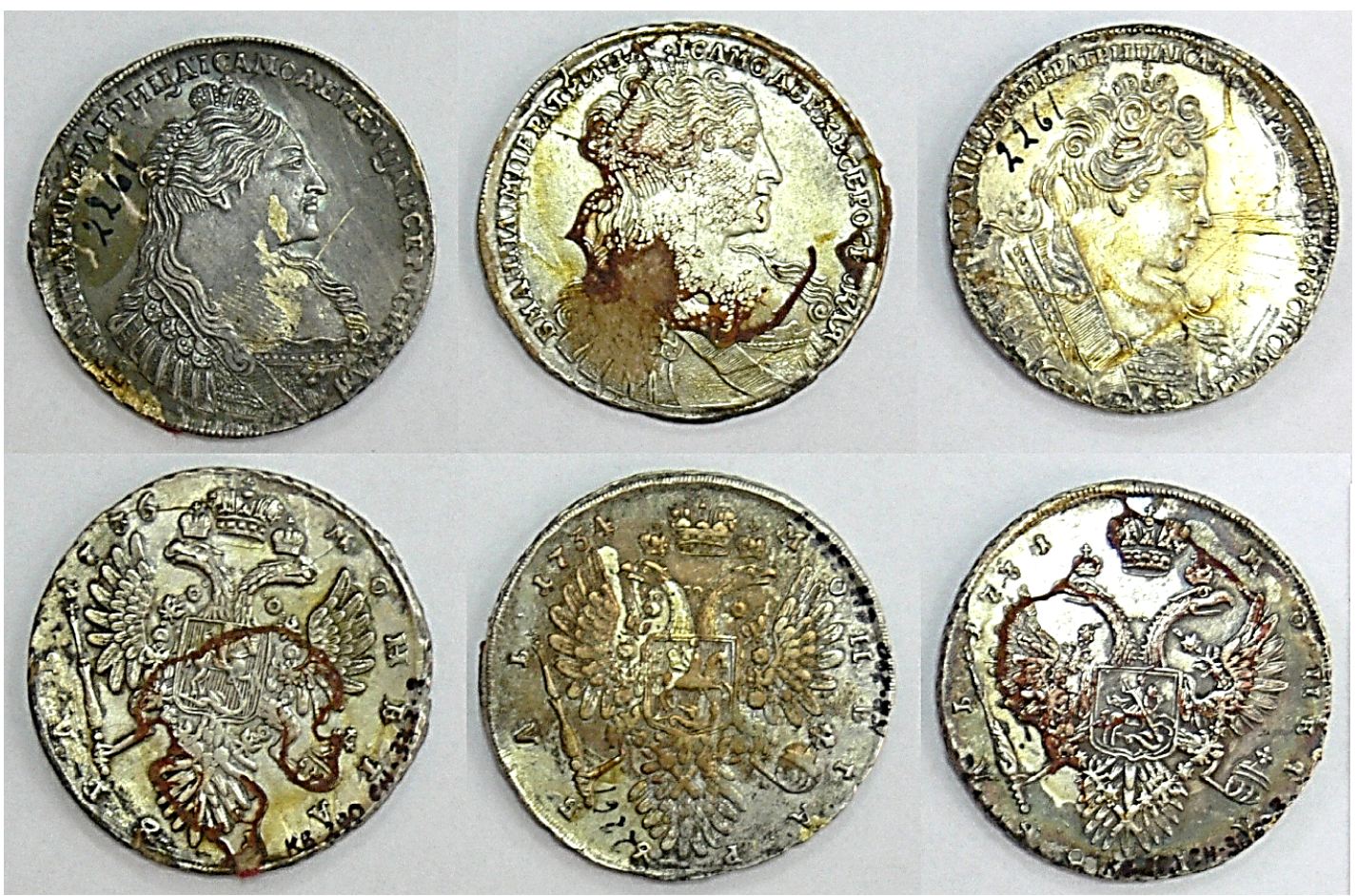

Рис. 4.

Російська імперія, рублі 1730- років. 